This paper is peer-reviewed pre-print submitted to EarthArXiv. The manuscript has been accepted at Earth and Planetary Science Letters and is available at: https://doi.org/10.1016/j.epsl.2021.117332

\title{
Downward-propagating eruption following vent unloading implies no direct magmatic trigger for the 2018 lateral collapse of Anak Krakatau
}

Kyra S. Cutler ${ }^{1,2^{*}}$, Sebastian F. L. Watt ${ }^{1}$, Mike Cassidy ${ }^{2}$, Amber L. Madden-Nadeau ${ }^{2}$, Samantha L. Engwell $^{3}$, Mirzam Abdurrachman ${ }^{4}$, Muhammad E. M. Nurshal ${ }^{4}$, David R. Tappin ${ }^{5,9}$, Steven N. Carey ${ }^{6}$, Alessandro Novellino ${ }^{5}$, Catherine Hayer ${ }^{7}$, James E. Hunt ${ }^{8}$, Simon J. Day ${ }^{9}$, Stephan T. Grilli, ${ }^{6,10}$, Idham A. Kurniawan $^{4}$ and Nugraha Kartadinata ${ }^{11}$

${ }^{1}$ School of Geography, Earth and Environmental Sciences, University of Birmingham, Edgbaston, Birmingham, B15 2TT, UK

2 Department of Earth Sciences, University of Oxford, South Parks Road, Oxford OX1 3AN, UK

${ }^{3}$ British Geological Survey, The Lyell Centre, Research Avenue South, Edinburgh EH14 4AP, UK

${ }^{4}$ Faculty of Earth Sciences and Technology, Institut Teknologi Bandung, Jalan Ganesa No. 10 Bandung 40132, West Java, Indonesia

${ }^{5}$ British Geological Survey, Nicker Hill, Keyworth, Nottingham NG12 5GG, UK

${ }^{6}$ Graduate School of Oceanography, University of Rhode Island, Narragansett, R.I 02882, USA

${ }^{7}$ Department of Earth and Environmental Sciences, The University of Manchester, Oxford Road, Manchester M13 9PL, UK

${ }^{8}$ National Oceanography Centre, Waterfront Campus, University of Southampton, European Way, Southampton, SO14 3ZH, UK

${ }^{9}$ Institute for Risk and Disaster Reduction, University College London, London, WC1E 6BT, UK

${ }^{10}$ Department of Ocean Engineering, University of Rhode Island, Narragansett, R.I 02882, USA

${ }^{11}$ Volcano Research and Monitoring Division, CVGHM - Geological Agency of Indonesia, Jl. Diponegoro No. 57, Bandung, 40228, Indonesia

* Corresponding author at: Department of Earth Sciences, University of Oxford, South Parks Road, Oxford OX1 3AN, UK 


\begin{abstract}
The lateral collapse of Anak Krakatau volcano, Indonesia, in December 2018 highlighted the potentially devastating impacts of volcanic edifice instability. Nonetheless, the trigger for the Anak Krakatau collapse remains obscure. The volcano had been erupting for the previous six months, and although failure was followed by intense explosive activity, it is the period immediately prior to collapse that is potentially key in providing identifiable, pre-collapse warning signals. Here, we integrate physical, microtextural and geochemical characterisation of tephra deposits spanning the collapse period. We demonstrate that the first post-collapse eruptive phase (erupting juvenile clasts with a low microlite areal number density and relatively large microlites, reflecting a crystal-growth dominated regime) is best explained by instantaneous unloading of a relatively stagnant upper conduit. This was followed by the second post-collapse phase, on a timescale of hours, which tapped successively hotter and deeper magma batches, reflected in increasing plagioclase anorthite content and more mafic glass compositions, alongside higher calculated ascent velocities and decompression rates. The characteristics of the post-collapse products imply downward propagating destabilisation of the magma storage system as a response to collapse, rather than precollapse magma ascent triggering failure. Importantly, this suggests that the collapse was a consequence of longer-term processes linked to edifice growth and instability, and that no indicative changes in the magmatic system could have signalled the potential for incipient failure. Therefore, monitoring efforts may need to focus on integrating short- and long-term edifice growth and deformation patterns to identify increased susceptibility to lateral collapse. The post-collapse eruptive pattern also suggests a magma pressurisation regime that is highly sensitive to surface-driven perturbations, which led to elevated magma fluxes after the collapse and rapid edifice regrowth. Not only does rapid regrowth potentially obscure evidence of past collapses, but it also emphasises the finely balanced relationship between edifice loading and crustal magma storage.
\end{abstract}

\title{
volcanic lateral collapse | magma ascent | microlites | Anak Krakatau | rapid decompression | post- collapse volcanism
}

\section{Corresponding author email: kyra.cutler@stx.ox.ac.uk}

\section{Highlights:}

- Reconstruction of Anak Krakatau's eruptive activity following Dec. 2018 collapse.

- No evidence for the collapse being triggered by intrinsic magmatic changes.

- Failure resulted from extensive instabilities, accumulated from edifice growth.

- Sudden unloading perturbed the magmatic system, causing intense volcanic activity.

- Monitoring edifice growth may isolate areas prone to edifice instability. 


\section{Graphical abstract:}

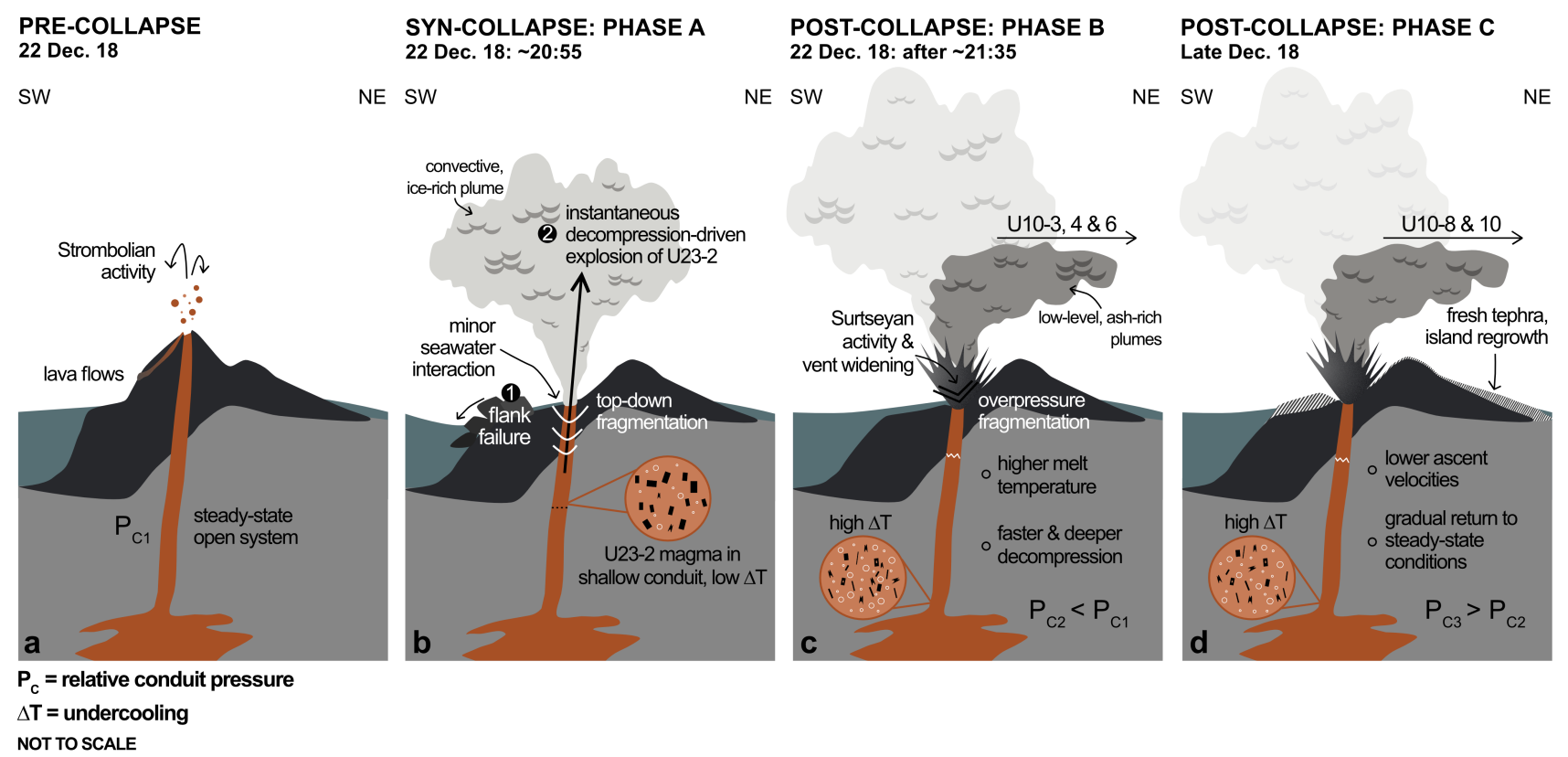

\section{Introduction}

Landslides generated by volcanic flank failure are significant hazards that can cause destructive tsunamis in island settings (e.g., Rosi et al., 2019; Watt et al., 2019). Due to their relatively low frequency, very few volcanic lateral collapses have been well observed, and there remains a limited understanding of their precursors. Determining the trigger(s) for collapse is often difficult, as edifice instability can develop from a range of factors including gravitational and structural weaknesses, shallow magmatic intrusions and hydrothermal alteration (e.g., McGuire, 2003; Reid, 2004). However, it is important to constrain the factors driving failure, and particularly whether shifts in magmatic activity are implicated, in order to develop a systematic monitoring framework that could potentially identify signals of incipient collapse.

The lateral collapse of Anak Krakatau, Indonesia, on 22 December 2018, which induced a tsunami causing over 400 fatalities on surrounding coastlines (Grilli et al., 2019), both highlights the impacts of such events and provides an opportunity to better understand the processes that drive edifice collapse. Anak Krakatau is a small stratovolcano within the Sunda Strait, positioned on the NE edge of the 1883 Krakatau caldera (Deplus et al.,1995). The volcano emerged above sea level in 1927, developing rapidly through frequent eruptions to a pre-collapse height of $\sim 330 \mathrm{~m}$ (Grilli et al., 2019). Collapse of its SW flank, with a volume of $0.18-0.31 \mathrm{~km}^{3}$ (Hunt et al., 2021), occurred six months into an eruption phase characterised by Strombolian, Vulcanian and effusive activity. Although this activity was typical of previous decades (e.g., Abdurrachman et al., 2018), it involved a relatively elevated magma flux (Walter et al., 2019). Infrared data from the Moderate Resolution Imaging Spectroradiometer (MODIS) revealed the volcano's highest thermal levels since MODIS measurements began in 2000. However, these were particularly elevated during late September 2018 (Walter et al., 2019), rather than showing a clear temporal progression culminating in collapse. It thus remains unclear if the collapse was initiated by a discrete and identifiable shift in magmatic activity, or if it resulted from longer-term destabilising processes. What is clear is that the collapse was accompanied (as far as the temporal resolution limits of geophysical 
observations can constrain) and/or immediately followed by intense explosive activity (e.g., Perttu et al., 2020). The collapse cut the active conduit beneath sea level, resulting in Surtseyan eruptions that produced extensive ash deposits, rapidly buried the collapse scar, fed convective atmospheric plumes reaching 16-18 km (Prata et al., 2020), and involved a higher magma flux than anything recorded in recent decades (Gouhier and Paris, 2019). Here, we seek to determine the role of magmatic activity in the 2018 Anak Krakatau collapse, specifically addressing whether the intense accompanying volcanism was a driver or a consequence of edifice failure, by reconstructing magma ascent conditions spanning the syn- and post-collapse period. This is important not only to understand this particular event, but more generally to identify causes of edifice failure at both active and inactive volcanoes, to develop approaches for monitoring edifice stability, and to understand the relationship between surface mass redistribution and magma ascent behaviour (cf. Petrone et al., 2009; Watt, 2019).

\section{2018 eruption and collapse observations}

Observations spanning the collapse period provide important constraints for understanding eruptive behaviour, ash dispersal, and characteristics of the post-collapse tephra-stratigraphy. All times stated in this section are Western Indonesian Time (WIB; UTC + 7 hours).

The 2018 eruption began in late June (PVMBG, 2018). Discharge rates, calculated from MODIS data, indicate that the magma flux peaked in September, gradually waning after October. Intensified eruptions on 22 December produced another peak in activity, but discharge rates had reached comparable or higher levels on ten previous occasions between June and December (Walter et al., 2019). Fishers, familiar with the area and near the island during the collapse, reported that the activity on 22 December had increased but was not unusual (Perttu et al., 2020). Infrasound signals suggest intense activity started at $\sim 13: 00$ on 22 December, an interpretation confirmed by eyewitness reports (from the Javan coast) of audible and visible Strombolian eruptions. The infrasound signals were similar in intensity to those from elevated eruption phases in 1999 and October 2018 (Perttu et al., 2020).

Although the June-December 2018 activity was not atypical in style, it added an estimated $54 \mathrm{Mt}$ of rock onto Anak Krakatau's central cone and southern flank (Walter et al., 2019). South-westward flank deformation is identifiable from Interferometric Synthetic Aperture Radar (InSAR) prior to June 2018, and at an accelerated rate thereafter (Walter et al., 2019). Fissure development and fumarolic activity within the pyroclastic cone support these observations of gradual deformation (Hunt et al., 2021).

On 22 December 2018, plumes extending into the cloud base were observed from 14:30, with pulsatory Strombolian explosions peaking at $18: 30$ and a white plume descending to the shoreline, implying lava effusion (Perttu et al., 2020). The same authors report that fishers decided the island was too dangerous to return to after 19:00 and observed lightning in the Strombolian plume at 20:00; and that two highfrequency seismic signals between 19:50 and 20:00 are consistent with small-scale slope failures. In the hour before the collapse, Darwin Volcano Ash Advisory Centre registered a final pre-collapse plume at 
20:10 (Perttu et al., 2020). A cessation in audible explosions in the 30 minutes before the collapse broadly coincides with an infrasound signal pause of a few minutes (Walter et al., 2019), suggesting a pre-collapse break in surface activity (Perttu et al., 2020).

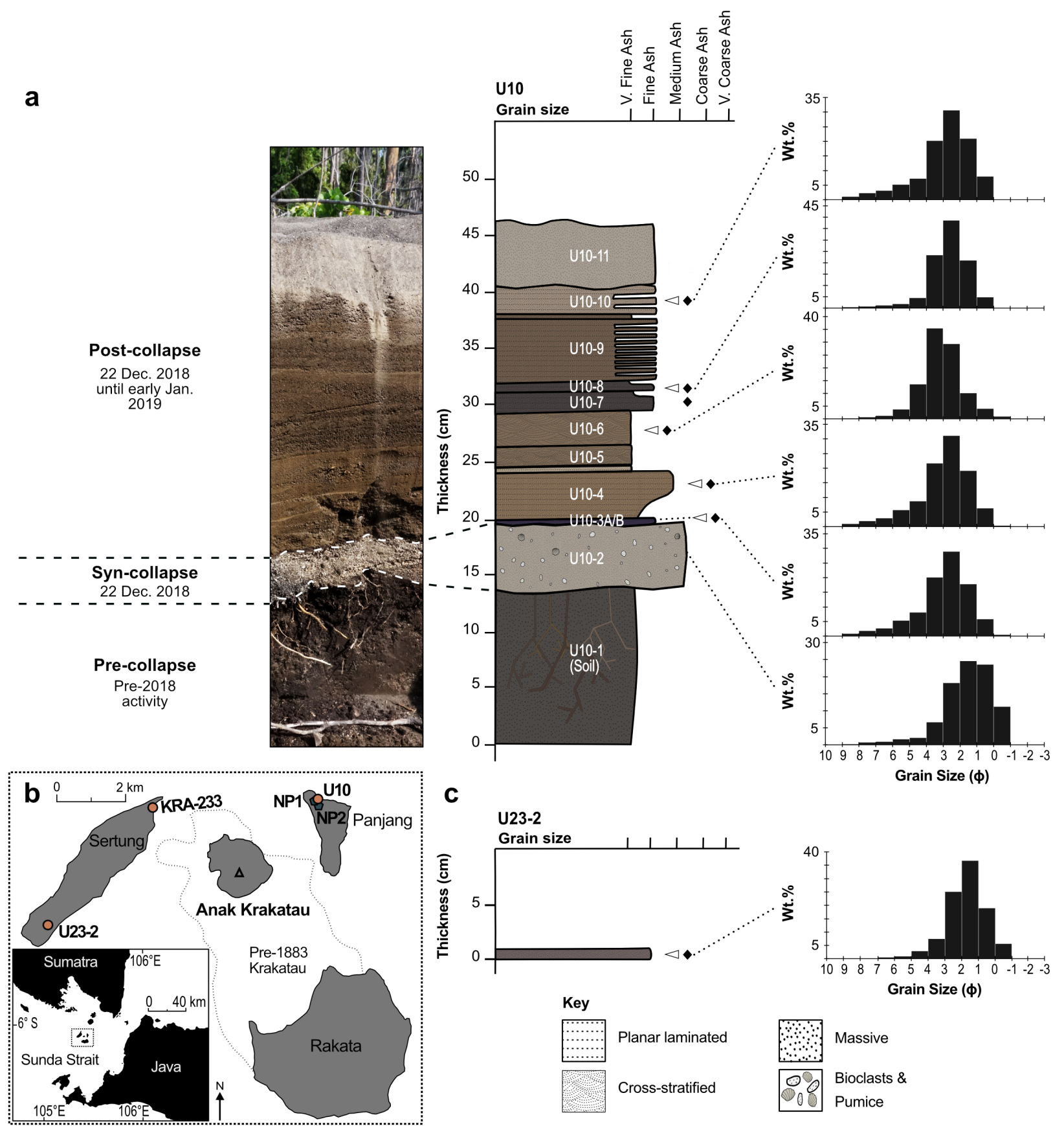

Figure 1

U10 and U23-2 stratigraphic sections and grain size data. a The physical characteristics of the U10 sequence on northern Panjang (image, sedimentary log and grain size distributions (sieved and laser diffraction data)). $\mathbf{b}$ Inset map showing location of Anak Krakatau and sample localities (main sites of KRA-233, U23-2 and U10 = peach circles; additional sites of NP1 and NP2 = dark blue pentagons). $\mathbf{c}$ The physical characteristics of the U23-2 ash from southern Sertung (sedimentary log and grain size distribution (sieved and laser diffraction data)). White triangles mark samples analysed texturally and black diamonds mark samples analysed geochemically (XRF and/or EPMA). 
The main collapse occurred in a single stage of movement as indicated by tsunami observations and modelling (Grilli et al., 2019; timed at 20:55-57), eyewitness accounts (Perttu et al., 2020), as well as seismic (20:55:49) and infrasound signals (20:55:51) (Walter et al., 2019; Perttu et al., 2020; Ye et al., 2020; all consistent with a SW-moving landslide source). There is no evidence for an unusually large explosion preceding collapse (Perttu et al., 2020), although the failure is bracketed by relatively highfrequency infrasound signals, two minutes before and 1.5 minutes afterwards. The former, at 20:54, is also observed in seismic records; Walter et al. (2019) interpret it as a possible explosion or earthquake signal that may have triggered the collapse, whereas Perttu et al. (2020) conclude that it is more consistent with a smaller-scale slope failure.

A brightness temperature reduction from Himawari-8 satellite data (11.2 $\mu \mathrm{m}$ channel) at $\sim 20: 55$ indicates a volcanic cloud reaching $\sim 16 \mathrm{~km}$, coincident with the collapse (Gouhier and Paris, 2019; Perttu et al., 2020). This signal has a sharp onset and peaks at $\sim 21: 00$, forming an ice-rich but ash-poor cloud advected to the SW (Prata et al., 2020) with ash emission lasting $\sim 40$ minutes (described as a blast-like explosion by Gouhier and Paris, 2019). Gouhier and Paris (2019) derive a higher mass-eruption rate for this specific plume $\left(9 \times 10^{5} \mathrm{~kg} / \mathrm{s}\right)$ than for the subsequent sustained phase $\left(5 \times 10^{5} \mathrm{~kg} / \mathrm{s}\right)$. Perttu et al. (2020) identify two further discrete explosive pulses at 22:25 and 22:55, progressing into sustained activity until 12:05 on 28 December. This supports the gradual development of an ice-rich convective plume from 22:30, identified by Prata et al. (2020), reaching sustained levels by 01:00 on 23 December, at heights of 16-18 km. The ice-rich plume, advected SW, formed above an ash-laden weak column, generated by intense Surtseyan eruptions, that advected eastwards at low altitudes (documented in aerial photographs on 23 December; Grilli et al., 2019; Prata et al., 2020; Hunt et al., 2021). This low-altitude, ash-rich plume deposited tephra on Panjang island, 2 km east of Anak Krakatau (Fig.1), causing severe vegetation damage, with fine ash reaching the Javan coast (authors' observations). Intense Surtseyan activity lasted for two weeks, divided into three phases by Gouhier and Paris (2019) (22-27 December, 28-29 December, 3-6 January 2019) and two phases by Perttu et al. (2020) (22-28 December; 30 December to early January 2019).

Current observations, outlined above, demonstrate that the pre-collapse eruptive activity was intense but not unusual. There is no evidence of activity strongly accelerating in the hours before collapse; behaviour on 22 December represented a renewal of vigorous eruptions, but output peaked three months beforehand. A powerful explosive eruption accompanied the collapse, and was distinct from the sustained activity that followed within a few hours, with infrasound signals, satellite observations and aerial photographs suggesting an immediate switch from Strombolian to Surtseyan behaviour as water infiltrated the vent.

\section{Tephra deposits}

Ash samples (Supplementary Table 1) were collected from five localities on Panjang and Sertung, islands respectively east and west of Anak Krakatau. Access difficulties limited sampling to one site on Sertung, U23-2 (6.38 km SW of the vent; Fig.1). This was collected in healthy forest, on level ground, at 
$\sim 100 \mathrm{~m}$ altitude and beyond the tsunami inundation limit. The dark volcanic ash sample occurred at the surface as a $1-\mathrm{cm}$ thick structureless layer mixed with leaf litter above an organic soil, consistent with a fall deposit. U23-2 is aligned with the south-westward dispersal of the high-level, ice-rich plume described above, but not with the E-advected low-level plume. Visual and satellite observations show no evidence of post-collapse vegetation damage on Sertung. In contrast, significant ash deposition stripped leaves and branches from the dense forest on Panjang (Fig.S1), consistent with observations of ash-laden plumes drifting over the island for several days after the collapse. On Panjang, surface pits at four sites exposed a well-bedded ash stratigraphy consistent with predominant fall deposition, exceeding $20 \mathrm{~cm}$ in places (excluding remobilised surface deposits). At site U10, a flat, open area $\sim 50 \mathrm{~m}$ from the shore on north Panjang, $\sim 5 \mathrm{~m}$ above high-tide level and $4.09 \mathrm{~km}$ from the vent, these deposits directly overlie a pumicerich sand layer mixed with sparse marine shells, deposited on top of organic soil (Fig.1a). A comparable ash stratigraphy was observed further inland (Fig.S2), but with the pumice layer absent.

Samples from U23-2 and U10 were selected for further textural and geochemical analysis. All analytical methods are described in Appendix 1. For comparison, ash (KRA-233) from May 1997 (an earlier Strombolian eruption) was also analysed, collected from a fall deposit on Sertung (Fig.1b), $3.80 \mathrm{~km}$ from the vent.

\section{Results}

4.1. Physical overview of eruptive products

The physical features (i.e., grain size, componentry, exterior grain surfaces) of the 1997 ash (KRA-233) provide an insight into the products of pre-collapse (Strombolian) magma ascent and fragmentation conditions, which can be contrasted with the December 2018 samples (Fig.1a and c) to evaluate changes in eruptive behaviour. KRA-233 is poorly sorted (1.2 $\phi)$ with a unimodal grain-size distribution peak of 2-3 $\phi$ and a fine ash content of $13 \%$ ( $>4 \phi$ or $<63 \mu \mathrm{m}$; Wohletz, 1983). The sample is dominated by juvenile ash grains (84\%) that are predominantly glassy, black and angular (Fig. 2a and 2b; see Supplementary Table 1 for component descriptions).

U23-2 is poorly sorted ash (1.2 $\phi)$, with a unimodal grain size of 2-3 $\phi$, and comprises highly angular, juvenile grains (96\%) that appear fresh, glassy and glossy. The unimodal grain size characteristics and homogeneous physical appearance of U23-2 ash suggest it is the product of a single depositional event, rather than an amalgamated deposit from pre- or post-collapse activity (i.e. an upwind equivalent of the Panjang Surtseyan deposits). The highly angular ash fragments (Fig.2c) and relatively narrow grain-size range of U23-2 contrast with the U10 samples (Fig.1a and c), as do several characteristics discussed in later sections.

The U10 sequence can be subdivided into eight distinct ash units (some comprising multiple layers; U10-3 to U10-10), with a total thickness of $21 \mathrm{~cm}$ (excluding $>6 \mathrm{~cm}$ of structureless, reworked surficial ash), overlying a pumiceous sand (U10-2). Beneath this, a black soil (U10-1), rich in ash and rootlets, is inferred to derive from pre-2018 Anak Krakatau activity. U10-2 is a poorly sorted (1.4 $\phi)$ and structureless layer, defined by erosional contacts with a maximum thickness of $11 \mathrm{~cm}$. Sub-angular/sub-rounded cream 
pumice fragments dominate the layer (52\%), assumed to originate from local coastal exposures of the 1883 Krakatau ignimbrite (cf. Madden-Nadeau et al., 2021), alongside other volcanic clasts and minor $(<4 \%)$ marine biogenic material (gastropod shells, sponge spicules). Based on these characteristics and an absence of this layer at more elevated sites further inland (i.e., NP1 and NP2; Fig.S2), U10-2 is interpreted as a tsunami deposit resulting from the 2018 landslide (Fig.2d). Above this, the ash units are characterised by generally poor sorting (0.9-1.6 $\phi)$ and unimodal grain-size peaks at 2-3 $\phi$ with a fine ash content ranging from $\sim 8$ to $33 \%$. U10-3 (sampled twice; 3A capturing the bulk layer, and -3B the uppermost part to avoid contamination from $\mathrm{U} 10-2)$ is a thin $(0.5 \mathrm{~cm})$ and slightly indurated purple ash with an oxidised yellow-brown crust, containing the highest proportion of altered and lithic grains (19\%; Fig.2e) of any studied samples. U10-3 is also the only U10 unit that can be well-correlated, based on its distinctive colour, with other 2018 ash exposures on N Panjang (i.e., NP2-1; Fig.S2). Overlying this, U10-4 is an inverse graded, planar bedded brown ash overlain by a thin, very fine ash $(3.5 \mathrm{~cm}$ in total), dominated by juvenile grains $(95 \%)$ but with a generally duller and less angular appearance than U23-2. Grain characteristics are similar throughout the overlying sequence. U10-5 $(2.8 \mathrm{~cm})$ and U10-6 $(2.5 \mathrm{~cm})$ are very fine (modal peak, 3-4 $\phi$ ) brown ash beds, distinct from the rest of the sequence in displaying weak cross-stratification
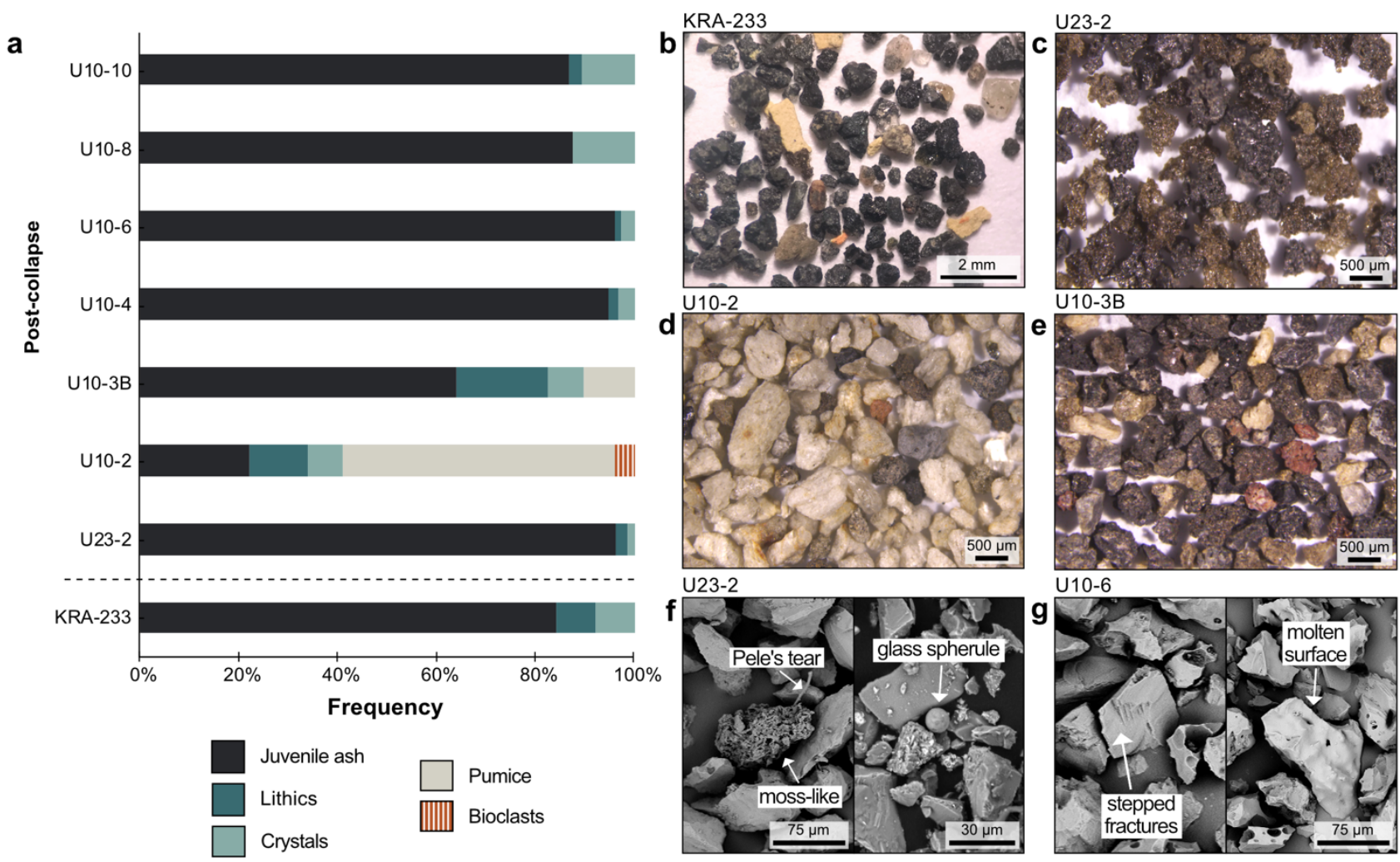

\section{Figure 2}

Component analysis and optical/secondary-electron (SE) SEM images. a Quantitative componentry of a 1997 ash sample (KRA-233) and the December 2018 ash samples (U23-2 and U10) using the $500 \mu \mathrm{m}-1 \mathrm{~mm}$ size fraction. b KRA-233 deposit, showing mostly black juvenile grains. c U23-2 ash deposit. Note the very high grain angularity and glassy nature of the grains. d U10-2 tsunami deposit, dominated by 1883 Krakatau pumice fragments. e U10-3B deposit, displaying more subangular grain morphologies and altered grains. f SE SEM images of U23-2 ash grains with brittle or ductile fragmentation features (63-125 $\mu \mathrm{m}$ size fraction). Left image displays a Pele's hair and a moss-like grain. Right image highlights a glass spherule. g SE SEM images of U10-6 ash grains with brittle or ductile fragmentation features (63-125 $\mu \mathrm{m}$ size fraction). Left image shows a grain with stepped fractures. Right image displays a grain with a molten surface. 
that becomes more developed near the top of the layers; these may reflect deposition from base surges rather than fallout. The U10-7 - U10-10 layers are again characterised by parallel planar bedded structures (Fig.1a). U10-7 (black medium ash; $2.5 \mathrm{~cm}$ ) and U10-8 (a similar deposit; $1 \mathrm{~cm}$ ) show slight normal grading, and U10-9 (2.7-5.5 cm in total; up to 10 individual beds on a few-mm scale) and U10-10 (a $2 \mathrm{~mm}$ very fine basal brown ash overlain by three normally graded beds; $3.2 \mathrm{~cm}$ ) display alternate fine and very fine ash beds. Based on its multi-bedded characteristics and aerial observations of NE/E-directed ash-rich plumes (PVMBG, 2018; Prata et al., 2020), we infer that the U10-3 - U10-10 sequence represents deposition from pulsatory post-collapse Surtseyan activity between 22 December and early January 2019, though we cannot correlate exact dates with individual layers.

\subsection{Exterior grain surfaces}

Scanning electron microscope (SEM) secondary-electron images of mounted ash grains were used to examine micro-scale features and potential differences in fragmentation modes between samples. Many grains from all samples display brittle features including stepped (Fig.2g) and conchoidal fractures, as well as river-line patterns that indicate fracturing under mixed-mode stresses (Hull, 1999). Additionally, many grains in U23-2 and $\mathrm{U} 10$ have secondary minerals (e.g., cubic $\mathrm{NaCl}$ ) and/or finer particles adhered to their surfaces; in some cases, these have annealed together, creating irregular moss-like grains (Fig.2f; Büttner et al., 2002). There are also infrequent occurrences ( 1\%) of ductile features in U23-2 and U10 including Pele's hairs, platy grains, fluidal grains, and grains with molten surfaces. A notable feature of U23-2 is the presence of smooth glass spherules (cf. Genareau et al., 2015), which are not observed in the U10 or KRA-233 samples.

\subsection{Ash morphology}

Additional morphological and textural analyses of ash grains were undertaken on SEM backscatteredelectron images of samples. Liu et al. (2015a) determined that proportions of dense (including free crystals and lithics) and vesicular grains (including glass shards) can be distinguished using a concavity index (Cl) threshold when plotting axial ratio against $\mathrm{Cl}$ (Fig.3). Concavity index combines solidity (solidity = grain area/grain convex hull) and convexity (convexity = convex hull perimeter/grain perimeter) parameters, while axial ratio compares the major and minor axes of the grains' best fit ellipse (Liu et al., 2015b).

U23-2 displays a high proportion of dense (79\%) to vesicular grains, averaged across three size fractions $(250-180 \mu \mathrm{m} ; 180-125 \mu \mathrm{m} ; 125-63 \mu \mathrm{m})$, characterised by a low concavity index $(\mathrm{Cl}<0.4)$ (Fig.3a). The dominance of planar, fractured grains supports the high angularity observed from the macrocomponentry of U23-2. By comparison, U10-3B and U10-4 (the lowermost 2018 Panjang deposits) have different morphologies, with higher proportions of vesicular (75 and $70 \%$, respectively) to dense grains (Fig.3b and c). In addition, there are slight variations between different size fractions: in U10-3B, the proportion of vesicular grains increases with larger grain size fractions, whereas the $\mathrm{Cl}$ peaks in the 125-180 $\mu \mathrm{m}$ size fraction of U10-4, representing higher glass shard content (Appendix 2). These quantitative morphological analyses are also consistent with vesicularity differences between samples 

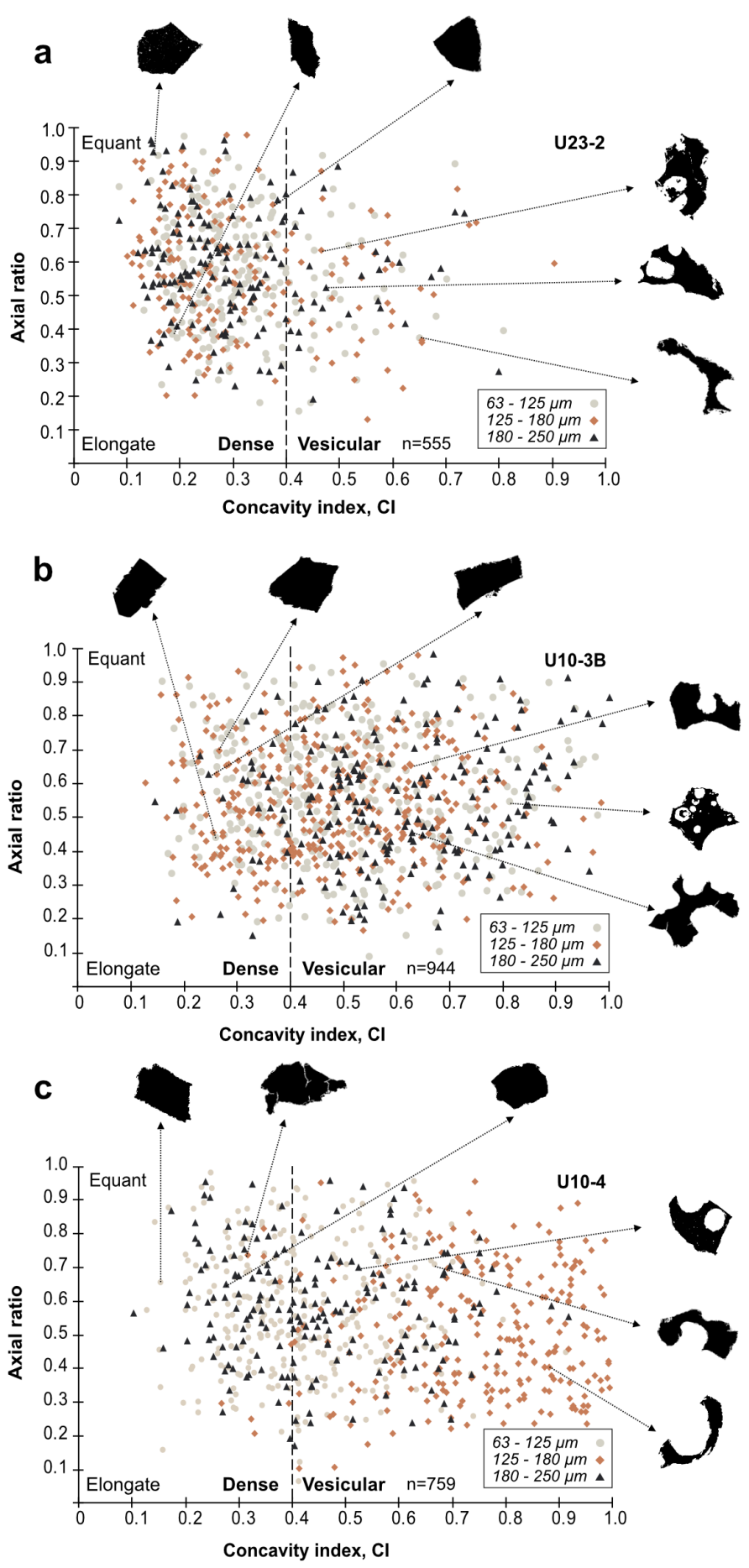

Figure 3

Graphs showing shape analysis of ash particles from U232 (a), U10-3B (b) and U10-4 (c) at three different grain size fractions $(63-125 \mu \mathrm{m}, 125-180 \mu \mathrm{m} \&$ 180-250 $\mu \mathrm{m})$. Concavity index $(\mathrm{Cl})$ is plotted against axial ratio, with dashed line $(\mathrm{Cl}=0.4)$ marking the threshold between dense (including free crystals and lithics) and vesicular grains (including glass shards), after Liu et al. (2015a). Binary images of examples of dense and vesicular grains from each deposit are labelled on each diagram.
(Appendix 2, Fig.S3 and Fig.S4). Morphometric analysis of multiple grain-size fractions was not undertaken for other units, but U10-10 (63-125 $\mu \mathrm{m}$ size fraction) shows comparable features to U103B and U10-4, and visual observations throughout the U10 sequence imply minor morphological variation.

4.4. Whole-rock and groundmass glass compositions

Both bulk rock (X-ray fluorescence) and groundmass glass (electron probe microanalysis; EPMA) compositions are summarised in Supplementary Table 2. U23-2 and all analysed U10 samples have a basaltic andesite bulk composition $\left(\mathrm{SiO}_{2}=54.1-55.4\right.$ wt. $\%, \mathrm{NaO}+\mathrm{K}_{2} \mathrm{O}=$ 4.3-4.4 wt.\%), maintaining the chemical homogeneity of pre-collapse (July 2018; Walter et al., 2019) and older (1993 to 2017; Gardner et al., 2013) samples $\left(\mathrm{SiO}_{2}=54.0-55.8\right.$ wt. $\%, \mathrm{NaO}+$ $\mathrm{K}_{2} \mathrm{O}=4.2-4.6$ wt. \%) (Fig.S5). Only U10-3 displays a subtle compositional difference, with a slightly higher loss on ignition value and elevated $\mathrm{SO}_{3}$ and $\mathrm{Cu}$ contents. Along with its discolouration and lithic abundance (Fig. 2e), this may reflect the relatively higher proportion of hydrothermally altered material in this deposit.

All groundmass glasses (Fig.S6) are andesitic $\left(\mathrm{SiO}_{2}=57.6-63.0\right.$ wt.\%). Hierarchical cluster analyses distinguish two distinct sample groups based on major element glass compositions (Appendix 1 and Fig.4). Early post-collapse samples (U10-3, U10-4 and U10-6) form one cluster, defined by elevated $\mathrm{MgO}$ and $\mathrm{CaO}$, with reduced $\mathrm{K}_{2} \mathrm{O}$ and $\mathrm{SiO}_{2}$ contents. U10-3 forms a separate subdivision characterised by elevated $\mathrm{FeO}$ and $\mathrm{TiO}_{2}$, and low $\mathrm{Al}_{2} \mathrm{O}_{3}$ contents (Fig.S6). 
KRA-233 and U23-2, combined with later post-collapse samples (U10-8 and U10-10), comprise the other cluster.

\subsection{Phase assemblage}

EPMA and SEM analyses show that all studied samples contain a microlite (<100 $\mu \mathrm{m}$ in length), microphenocryst $(\sim 100 \mu \mathrm{m}-0.25 \mu \mathrm{mm})$ and phenocryst $(\sim 0.25-0.5 \mu \mathrm{mm})$ assemblage of plagioclase, orthopyroxene, olivine, clinopyroxene and titanomagnetite within a glass matrix.

Plagioclase is the most abundant phase ( $10-26 \%$ area) in all samples, predominantly exhibiting subhedral/euhedral phenocryst habits with normal, oscillatory and patchy zoning, and can occur as constituents of glomerocrysts. Variably resorbed cores and amoeboid melt inclusions are common features within phenocrysts. Plagioclase microlite morphologies in KRA-233 and U23-2 are dominantly tabular, with rare swallow-tail and skeletal forms in U23-2. The U10 samples contain more varied morphologies including tabular, acicular, skeletal, hopper and swallow-tail forms (Fig.5). Moreover, numerous feldspar microlites in $\mathrm{U} 10$ samples are surrounded by a thin Fe/Mg/Ti-enriched boundary layer (Fig.5e), formed when plagioclase growth rates exceed incompatible element diffusion rates in the melt (Honour et al., 2019). Microlites in all samples display a common main peak in anorthite content at $\mathrm{An}_{56}$ $(\mathrm{An}=$ molar $\mathrm{Ca} /(\mathrm{Ca}+\mathrm{Na}+\mathrm{K}) ; \mathrm{mol} \%)$. The microlite
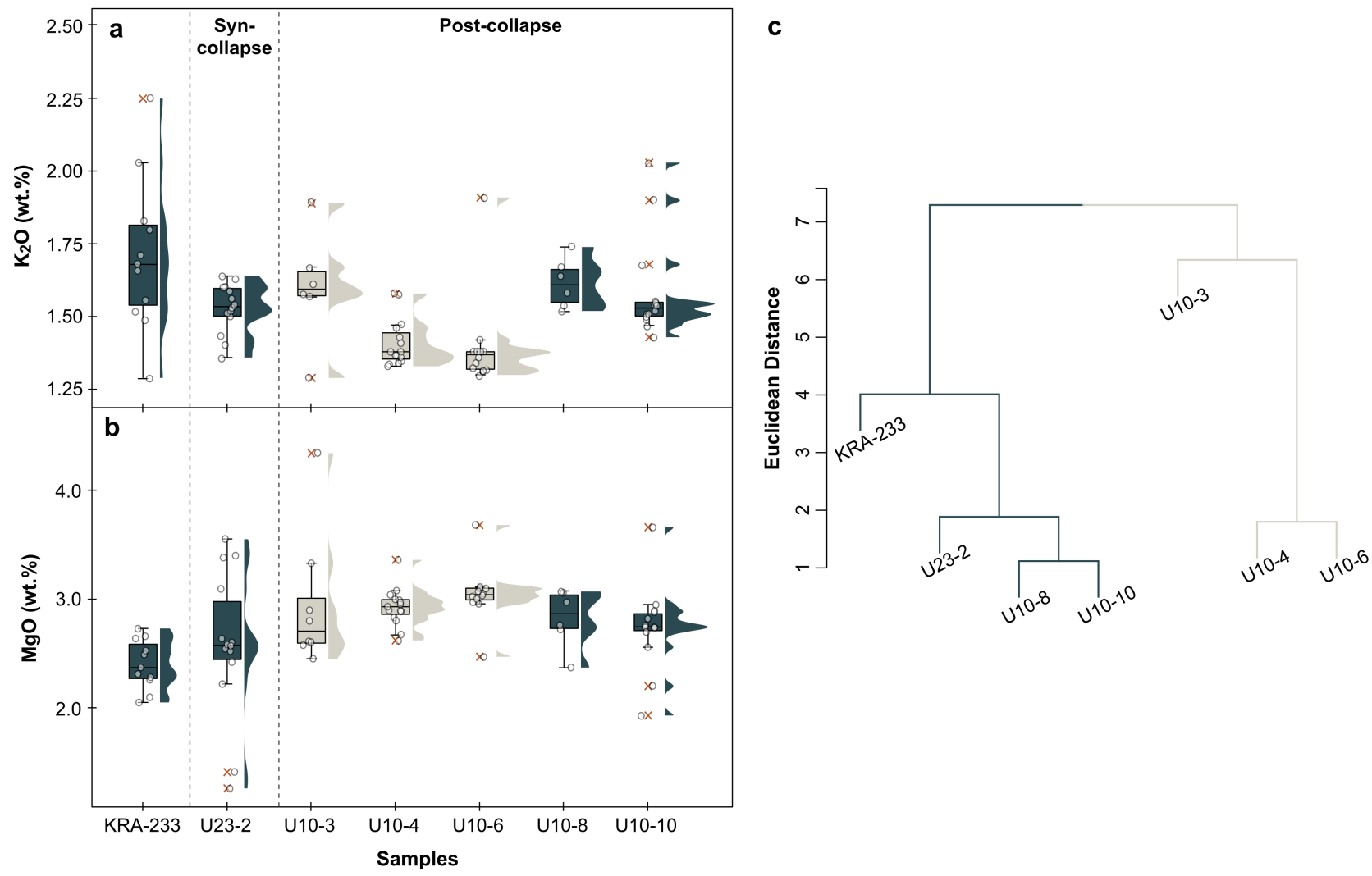

Figure 4

Glass compositions for the KRA-233 ( $n=11)$, U23-2 ( $n=14)$ and $U 10(U 10-3, n=8 ; U 10-4, n=15 ; U 10-6, n=12 ; U 10-8$, $\mathrm{n}=6$; $\mathrm{U} 10-10, \mathrm{n}=14$ ) samples. a and $\mathbf{b}$ Raincloud plots showing the subtle changes to $\mathrm{MgO}$ and $\mathrm{K}_{2} \mathrm{O}$ compositions spanning the collapse period (additional raincloud plots are presented in Supplementary Figure 4). Within the boxplots, the median value is highlighted by the black horizontal line and upper and lower quartiles are bounded by box dimensions. All raw data (white circles with dark grey outline) are shown with dark orange crosses representing outliers. c Hierarchical cluster dendrogram of samples based on the Euclidean distances between the average glass compositions for all main oxides. Colours used to distinguish clusters in the dendrogram correspond to the colours in the raincloud plots. 
a

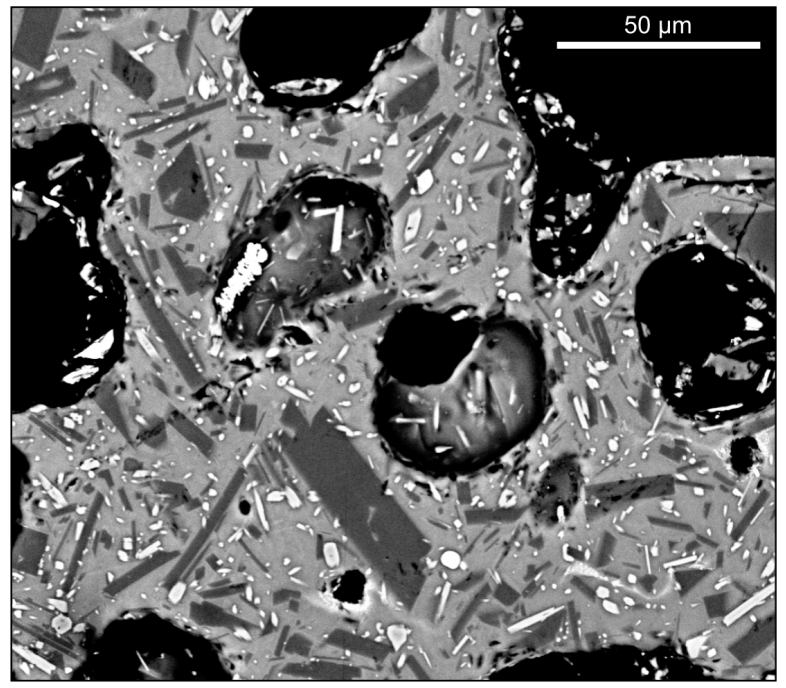

C

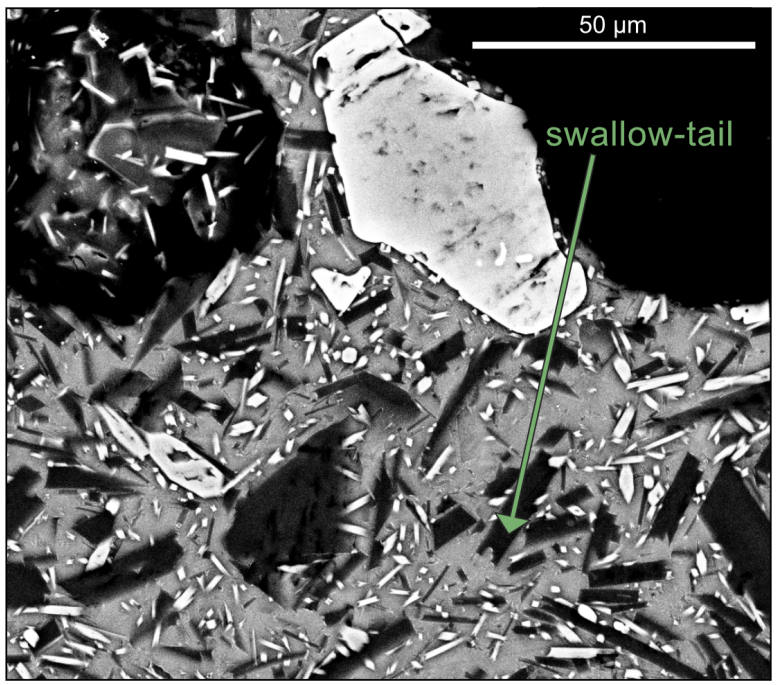

e

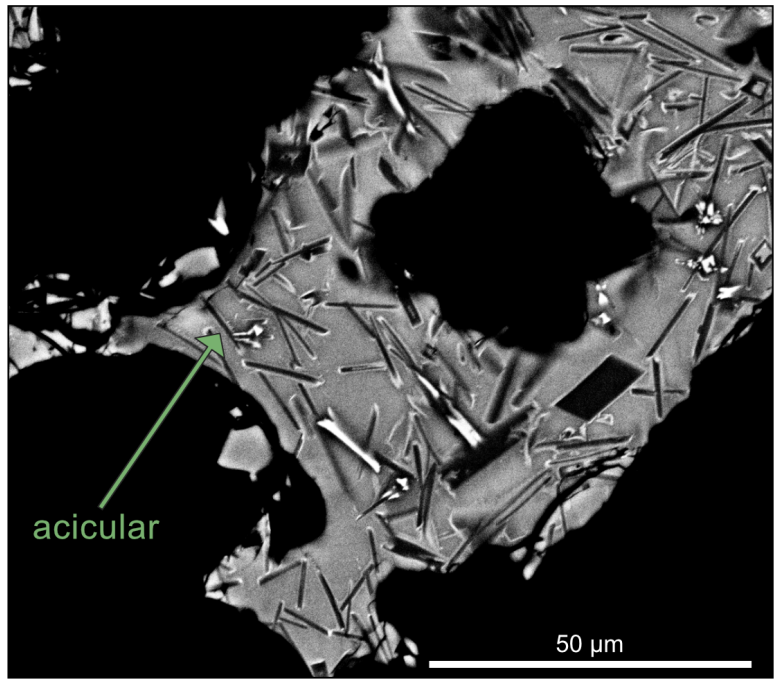

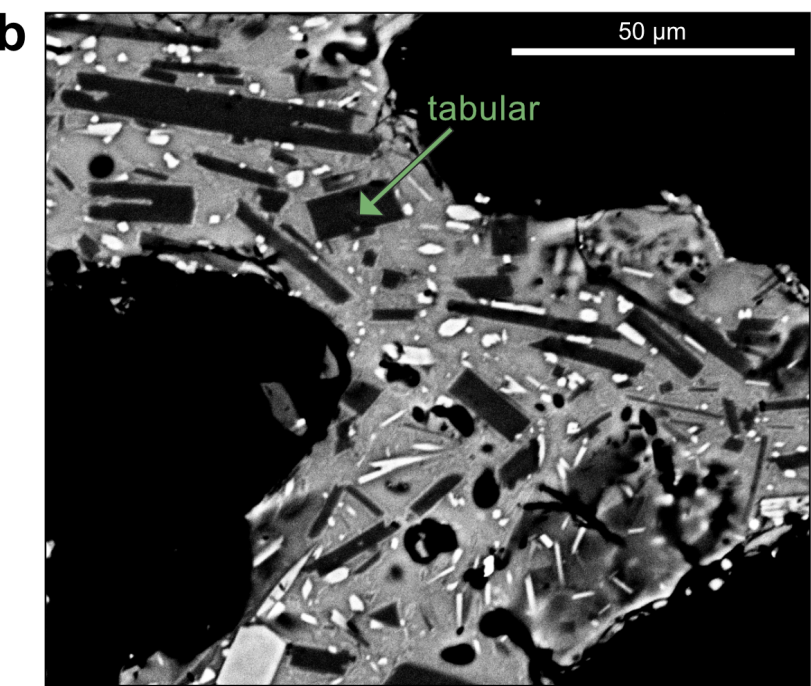
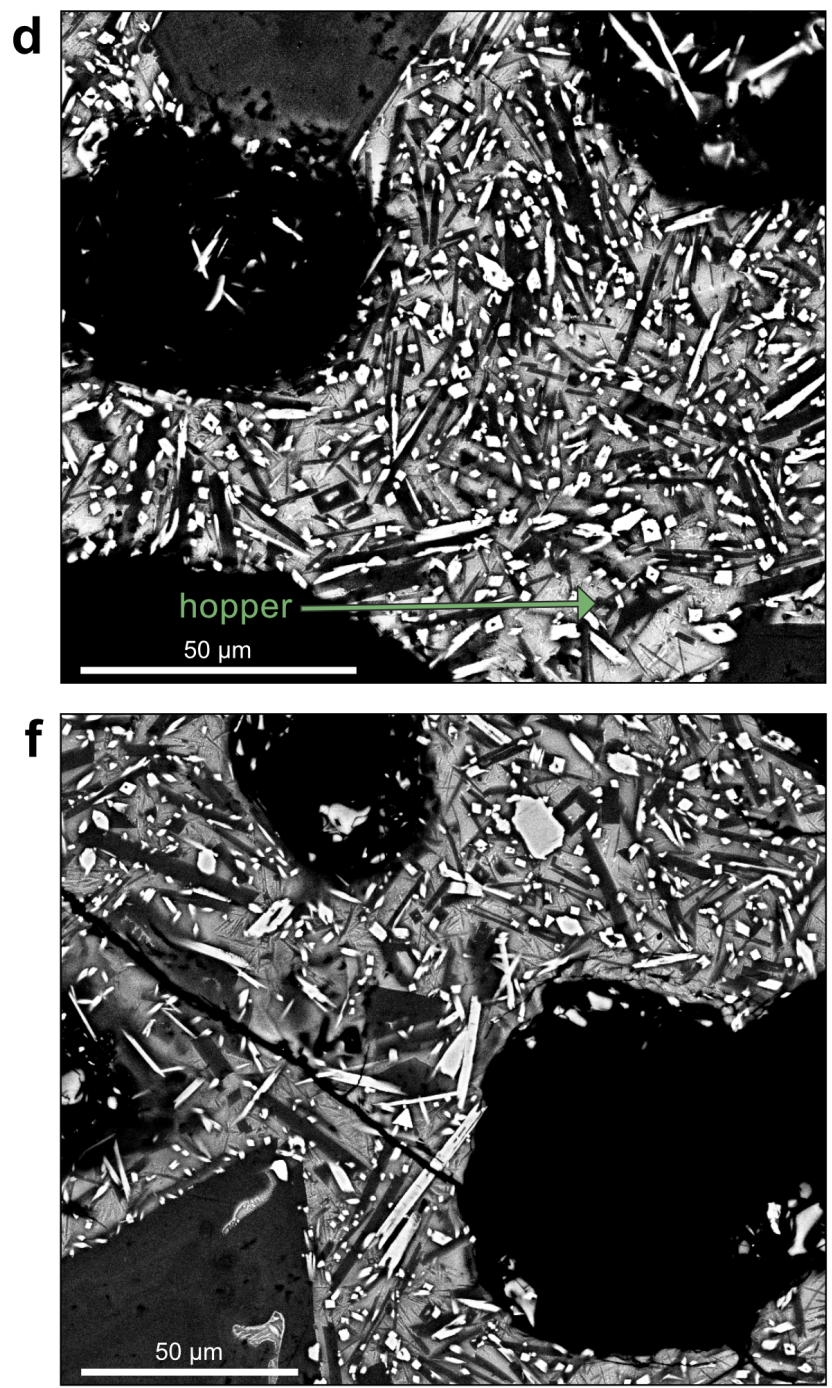

Figure 5

Backscattered-electron (BSE) SEM images of vesicular scoria with plagioclase feldspar microlite textures. a Tabular microlites in KRA-233. b Tabular and swallow-tail microlites in U23-2. c Tabular, acicular and swallowtail microlites in U10-3B. d Hopper and acicular microlites in U10-4. e Acicular microlites with prominent Ferich compositional boundary layers in U10-6. f Acicular, hopper and swallow-tail microlites in U10-10. 

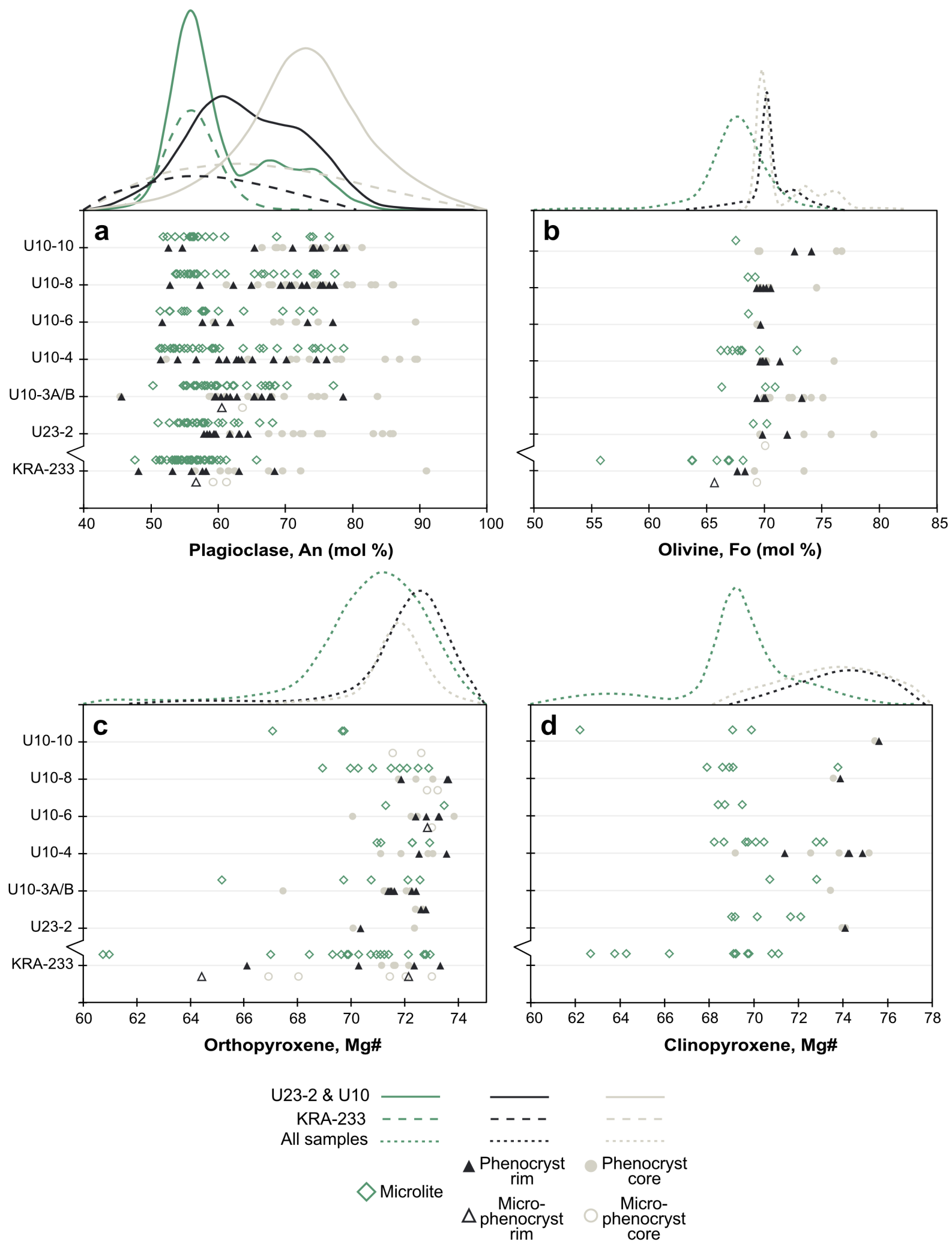

\section{Figure 6}

EPMA chemical compositions of plagioclase, olivine, and pyroxene shown for KRA-233, U23-2 and U10. a Anorthite contents in microlites $(n=192)$, microphenocrysts and phenocrysts of plagioclase $(n=76$ core-rim pairs). b Forsterite contents in microlites $(n=25)$, microphenocrysts and phenocrysts of olivine $(n=22$ corerim pairs). $\mathbf{c}$ and $\mathbf{d} \mathbf{M g \#}$ for orthopyroxene (opx) (c) and clinopyroxene (cpx) (d) in microlites (opx, $\mathrm{n}=44$; $\mathrm{cpx}$, $n=37$ ), microphenocrysts and phenocrysts (opx, $n=25$ core-rim pairs; cpx, $n=7$ core-rim pairs). Kernel density estimates are plotted on top of each diagram illustrating main distributions across all samples (and distinguishing KRA-233 from the 2018 samples in plagioclase). 
Table 1

Textural characteristics of plagioclase microlites in vesicular microlite-rich scoriae from Anak Krakatau, with estimated ascent rates (KRA-233: 1997 Strombolian sample; U23-2 and U10- : 2018 samples; $n$ denotes the number of crystals analysed).

\begin{tabular}{|c|c|c|c|c|c|c|c|c|c|}
\hline \multirow[b]{2}{*}{ Sample } & \multicolumn{7}{|c|}{ 2D areal measurements } & \multirow{2}{*}{$\begin{array}{c}\text { 3D volumetric } \\
\text { measurements } \\
N_{V}\left(\mathrm{~mm}^{-3}\right)\end{array}$} & \multirow[b]{2}{*}{$\begin{array}{l}\text { Mean } \\
\text { ascent rate } \\
\left(\mathrm{m} \mathrm{s}^{-1}\right)\end{array}$} \\
\hline & $\mathbf{n}$ & $\begin{array}{c}\text { Image } \\
\text { area } \\
\left(\mu \mathrm{m}^{2}\right)\end{array}$ & $\begin{array}{c}\mathrm{N}_{\mathrm{A}} \\
\left.{ }_{2}\right)\end{array}$ & $\begin{array}{l}\text { Plag. } \\
\text { area } \\
\%\end{array}$ & $\begin{array}{c}\text { Plag. } \\
\text { area } \\
\text { fraction, } \\
\varphi\end{array}$ & $\begin{array}{l}\text { Mean } \\
\text { crystal } \\
\text { size, } S_{n} \\
\left(\mu \mathrm{m}^{2}\right)\end{array}$ & $\begin{array}{l}\text { Aspect ratio } \\
\text { (major/minor } \\
\text { axis) }\end{array}$ & & \\
\hline KRA-233 & 403 & 35561 & 11194 & 16.28 & 0.23 & 4.54 & 4.08 & 2466412 & 0.16 \\
\hline U23-2 & 784 & 65328 & 12062 & 14.59 & 0.25 & 4.56 & 4.19 & 2644251 & 0.14 \\
\hline U10-3A & 914 & 33612 & 26882 & 24.10 & 0.35 & 3.58 & 4.14 & 7501290 & 0.09 \\
\hline U10-3B & 1110 & 27164 & 41111 & 22.93 & 0.27 & 2.56 & 4.09 & 16074394 & 0.14 \\
\hline U10-4 & 980 & 22475 & 44545 & 23.40 & 0.38 & 2.92 & 5.93 & 15278638 & 0.81 \\
\hline U10-6_1 & 716 & 43873 & 16273 & 10.43 & 0.15 & 3.04 & 7.28 & 5349256 & 0.35 \\
\hline U10-6_2 & 774 & 53431 & 14604 & 13.56 & 0.24 & 4.03 & 5.91 & 3619626 & 0.34 \\
\hline U10-8_1 & 577 & 21186 & 27476 & 25.63 & 0.36 & 3.60 & 5.14 & 7631114 & 0.18 \\
\hline U10-8_2 & 507 & 37593 & 13342 & 16.17 & 0.19 & 3.78 & 5.55 & 3527747 & 0.10 \\
\hline U10-10 & 1215 & 32271 & 37969 & 21.56 & 0.33 & 2.96 & 5.79 & 12843341 & 0.31 \\
\hline
\end{tabular}

compositional range in KRA-233 and U23-2 is similar (An48-68). In contrast, U10 microlites extend to An79 (Fig.6a), with subsidiary peaks at $A n_{68}$ and $A n_{75}$. For all samples, microphenocryst and phenocryst core compositions are more primitive (i.e. more anorthitic; ranges of An62-91 and An45-89, respectively) than corresponding rims (An48-68 and $A_{51-79}$, respectively). Rims also show more primitive compositions progressively higher up the $\mathrm{U} 10$ stratigraphy (U23-2 is also among the least primitive, but does not extend to anorthite contents as low as KRA-233); core compositions exhibit the same trend, albeit less strongly (Fig.6a). The anorthite content range is consistent with data from 1970-2002 lava flows (Camus et al., 1987; Dahren et al., 2012).

KRA-233 and U23-2 have minor proportions of mafic minerals (i.e., orthopyroxene, olivine, clinopyroxene and oxides) (areal mean $\sim 6 \%$ ), whereas U10 samples contain nearly double the proportion (areal mean $\sim 11 \%$ ). Pyroxene, olivine, and oxide phenocrysts and microphenocrysts in all samples have anhedral to euhedral crystal habits with no zoning observed. Microlite morphologies are largely tabular, equant or skeletal. Orthopyroxene (opx) is more dominant than clinopyroxene (cpx), but both have comparable Mg-numbers (Mg\#; molar $\mathrm{Mg} /(\mathrm{Mg}+\mathrm{Fe})$ ) for core-rim pairs (orthopyroxene, Mg\#66-74; clinopyroxene, Mg\#69-76); groundmass values generally fall below Mg\#70, consistent with 1990-2002 lava flows (Mg\#61-74, opx; Mg\#73-77, cpx; Dahren et al., 2012). Forsterite content (Fo = molar Mg/(Mg + Fe); mol $\%$ ) of olivine in phenocryst core-rim pairs (Fo69-80) and microlites (Fo66-73) for the U23-2 and U10 samples 
are slightly more primitive than in rocks erupted in the 1970s (Camus et al.,1987) and KRA 233 (Fo56-68, microlites; Fo62-73, cores and rims) (Fig.6b).

\subsection{Microtextural observations}

2D microlite analysis was conducted on dark vesicular, microlite-rich grains (Fig.7; Fig.S7) with a glassy lustre; these are inferred to represent juvenile material (D'Oriano et al., 2014), with their crystallisation fabrics assumed to record primary ascent conditions. All 2D textural data are summarised in Table 1. Plagioclase areal number density $\left(\mathrm{N}_{\mathrm{A}}\right)$, which defines the number of groundmass feldspars per unit area $\left(\mathrm{mm}^{-2}\right)$, is lowest in the $1997 \mathrm{KRA}-233$ sample $\left(11,194 \mathrm{~mm}^{-2}\right) . \mathrm{N}_{\mathrm{A}}$ in U23-2 is also relatively low $(12,062$ $\left.\mathrm{mm}^{-2}\right)$, whereas $\mathrm{U} 10-4$, early in the post-collapse Surtseyan sequence, has the highest density $(44,545$ $\mathrm{mm}^{-2}$ ). U10-3 (both $\mathrm{U} 10-3 \mathrm{~A}$ and $\mathrm{B}$ ) is slightly lower than $\mathrm{U} 10-4$, and later $\mathrm{U} 10$ samples range between 13,342 and $37,969 \mathrm{~mm}^{-2}$.

Plagioclase microlite crystallinity $(\varphi)$ describes the fraction that feldspar microlites occupy within the groundmass, excluding all vesicles and microphenocrysts/phenocrysts (Hammer et al., 2000). A plot of $\mathrm{N}_{A}$ versus $\varphi$ reveals that $\mathrm{U} 23-2$ and KRA-233 have similar characteristics (Fig.S8). Later U10 samples have slightly higher $N_{A}$ and lower $\varphi$, while U10-4 and, to a lesser extent, U10-3A/B show much higher values of both parameters (Fig.S8). The mean crystal sizes (Sn) of all samples range from $\sim 2.56$ to $4.56 \mu \mathrm{m}$; microlites are the smallest in U10-3B and largest in U23-2. A negative correlation between $N_{A}$ and $S_{n}$ indicates that samples either have high numbers of small microlites or the reverse (Fig.S8). Feldspar aspect ratios (major/minor axis) for U10-4, U10-6, U10-8 and U10-10 are high (5.14 - 7.28), representing more elongated crystal habits, whereas KRA-233, U23-2 and U10-3A/B have lower ratios (4.08 - 4.19), defining more tabular crystals.

\subsubsection{Ascent rates}

To assess approximate ascent rates, we used the microlite number density (MND) exsolution rate meter of Toramaru et al. (2008). Although this explicitly relates to microlite nucleation depths, it likely reflects a time-averaged ascent rate throughout the conduit (Murch and Cole, 2019). Since we used vesicular, microlite-rich grains, the textures reveal ascent conditions near the conduit walls, providing longer residence times for microlite crystallisation (Taddeucci et al., 2004); rates may thus be considered as minimum values.

Decompression rates $\left(\mathrm{dP}_{\mathrm{w}} / \mathrm{dz}\right)$ are estimated by:

$\left|\frac{d P_{w}}{d z}\right|=\frac{c}{b}\left(\frac{N v}{a}\right)^{\frac{2}{3}}$

where $b$ represents a constant ( 40 for plagioclase), $c$ is a function of water content $\left(C_{w}\right), N_{v}$ is microlite number volume, and $a$ is a calculation involving $C_{w}$ and glass silica content $\left(C_{s_{i}}\right)$. Microlite water contents were calculated (with temperature iteratively) using equation 23 of Putirka (2008) with the plagioclase-melt hygrometer of Waters and Lange (2015) in the Python3 tool, Thermobar (v.0.0.9; Wieser et al., 2021). Water contents range between 1.31 and $1.89 \mathrm{wt} . \%$ ( $\pm 0.35 \mathrm{wt} . \%$ uncertainty) for all samples except for U10-3 (0.97 wt.\%). It should be noted that $\mathrm{C}_{\mathrm{w}}$ and $\mathrm{C}_{\mathrm{Si}}$ are the most significant factors affecting 
decompression rate calculations; for instance, if $\mathrm{C}_{\mathrm{w}}$ has an error of $1 \%$, then resulting ascent rates can differ by $\sim 2 \%$.

Magmatic ascent velocities $\left(V_{n}\right)$ can then be calculated using the decompression rate:

$V_{n}=\frac{1}{\rho g}\left|\frac{d P_{w}}{d z}\right|$

where $\rho$ is the density of vesiculated magma (estimated using porosity values from ImageJ analysis and a $2700 \mathrm{~kg} \mathrm{~m}^{-3}$ magma density), $g$ is gravity, and $d P_{w} / d z$ is the decompression rate at the nucleation depth of feldspar microlites.

KRA-233 (the 1997 ash), U23-2 and U10-3 all yield relatively low mean ascent rates of $0.16,0.14$ and $0.12 \mathrm{~m} \mathrm{~s}^{-1}$, respectively. U10-4 shows a sharply elevated mean value of $0.85 \mathrm{~m} \mathrm{~s}^{-1}$, with rates then decreasing for later U10-samples $\left(0.10-0.35 \mathrm{~m} \mathrm{~s}^{-1}\right)$ (Fig.7).

\section{Discussion}

\subsection{Temporal and stratigraphic relationships}

Bulk magma compositions at Anak Krakatau from 1993 to 2018 show negligible changes, implying no compositionally different magma input associated with the 2018 lateral collapse. This corresponds with observations that pre-collapse activity was typical of previous eruptions, despite increased intensity (Perttu et al., 2020). Nonetheless, our textural and mineralogical observations reveal that $\mathrm{U} 23-2$ is distinct from the $\mathrm{U} 10$ sequence, while the basal U10 ash deposit (U10-3) also differs slightly from overlying units. U23-2 contrasts with the U10 samples morphologically, in its predominance of highly angular, dense clasts; it also has less primitive glass and mineral compositions, and its microlite crystallinity and estimated mean ascent rate are consistent with relatively slow processes, broadly corresponding with pre-collapse Strombolian conditions (i.e., KRA-233, the 1997

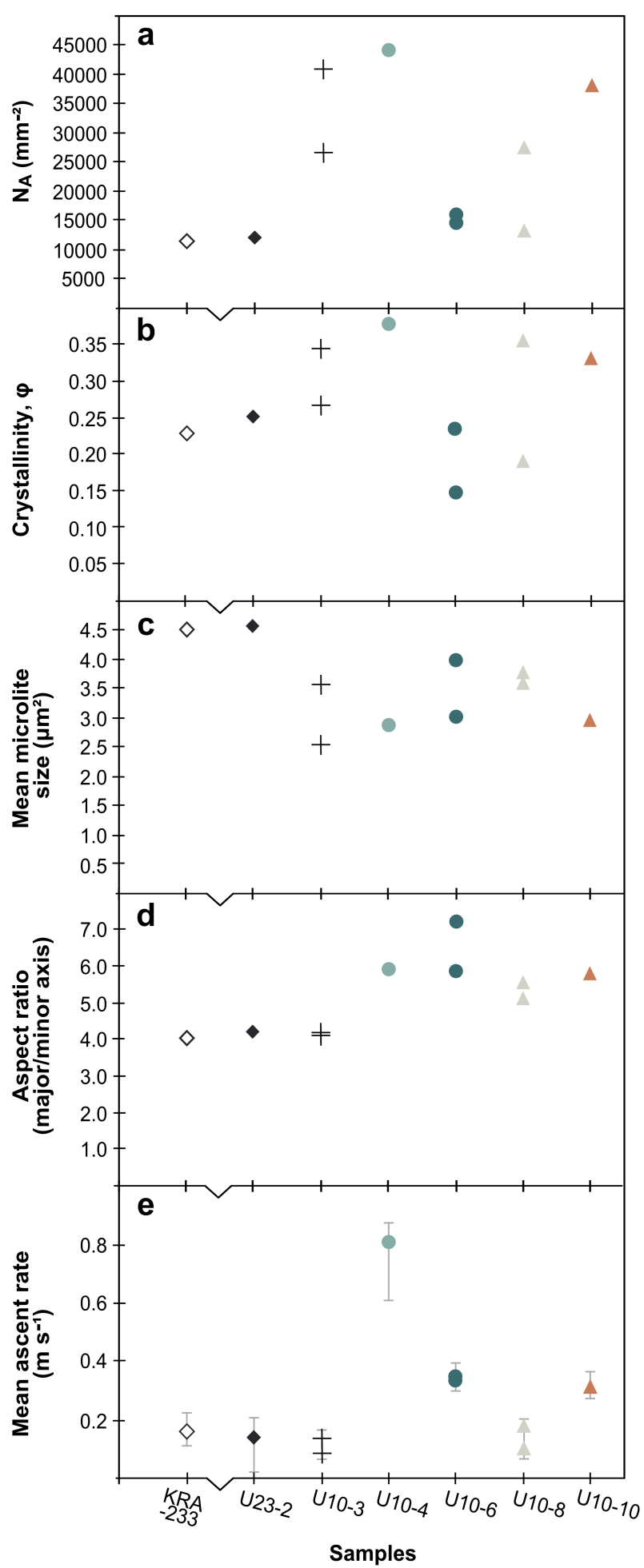

Figure 7

Temporal variations of $\mathrm{N}_{\mathrm{A}}(\mathbf{a})$, feldspar crystallinity (b), mean microlite size (c), aspect ratio (d) and mean ascent rate (e) (grey bars represent ascent rate ranges using a range of water content values estimated from plagioclase-melt hygrometry (Waters and Lange, 2015; Wieser et al., 2021) for plagioclase feldspar microlites in vesicular microlite-rich scoriae from KRA-233 (1997) and December 2018 samples (U23-2 and U10). 
ash). The overall homogeneity of U23-2 in both its deposit- and grain-scale characteristics suggests that it cannot be an upwind equivalent of $\mathrm{U} 10$, and was derived from a discrete event. We thus interpret U232 as a deposit from the initial explosive pulse that accompanied the lateral collapse at $\sim 20: 55$, involving the most intense mass eruption rate in the collapse period (Gouhier and Paris, 2019), its plume reaching $16 \mathrm{~km}$ in altitude and transported SW (e.g. Prata et al., 2020). This 'syn-collapse' explosion lasted $\sim 40$ minutes (Gouhier and Paris, 2019). The resulting 1-cm thick deposit on Sertung indicates that although this plume was relatively ash-poor, it was distinct from the ash-depleted, ice-dominated convective plumes sustained over the following days (Prata et al., 2020). The presence of glass spherules (cf. Genareau et al., 2015), observed only in U23-2, is consistent with material derived from a volcanic lightning-rich column (Fig.2f) (a notable feature of the high-level, ice-charged SW plume; Prata et al., 2020).

The U10-2 tsunami deposit provides an important time constraint for the Panjang deposits. Tsunami simulations indicate that maximum wave inundation at U10 occurred $\sim 6.3$ minutes after the collapse (Fig.S2c). Our interpretation suggests that U23-2 and U10-2 were deposited broadly synchronously, and if U23-2 was derived from the high-level syn-collapse plume, it might have an equivalent on Panjang. Such a deposit would be thin (given its upwind position) and potentially mixed with U10-2. However, we found no evidence of U23-2-type clasts within U10-2 or a U23-2-type layer beneath the basal purple ash elsewhere on Panjang. Any such layer would likely be difficult to distinguish from the underlying ash-rich soil. We are thus unable to provide further constraints on the timing of U10 ash deposits except that they post-date tsunami inundation and are consistent with all being derived from post-collapse Surtseyan activity.

\subsection{Unloading effects on microlite textures}

Edifice destruction causes an instantaneous pressure reduction in the underlying magmatic system (Pinel and Jaupart, 2005), which may be manifested in microlite textures that reveal decompression conditions during ascent (e.g., Preece et al., 2013). Variable microlite textures can be attributed to changes in effective undercooling ( $\Delta \mathrm{T}$, defined as $\mathrm{T}_{\text {liquidus }}-\mathrm{T}_{\text {magma; }}$ Kirkpatrick, 1981) during crystallisation. Low $\Delta \mathrm{T}$ and slow decompression produce fewer and larger crystals, developing under a crystal growth-dominated regime. In contrast, a nucleation-dominated regime arises at higher $\Delta T$ and faster decompression, forming numerous smaller microlites (e.g., Mollo and Hammer, 2017). Our samples can be divided into three phases that span the collapse. Phase A is recorded by U23-2, representing a crystal growth-dominated process, displaying the lowest areal microlite number density $\left(\mathrm{N}_{\mathrm{A}}\right)$, more tabular microlites, and the largest mean microlite size (Sn) (Lofgren, 1980). The textural similarities of U23-2 and KRA-233 indicate that both samples record steady-state conditions characteristic of the Strombolian feeder system that existed until the point of collapse, with relatively low ascent and decompression rates. The absence of textural disequilibrium suggests that U23-2 does not record a collapse-driven pressure perturbation, and we thus infer it derived from the surficial portion of the conduit, and that its fragmentation was an instantaneous, decompression-driven blast-like response to edifice failure (e.g. Alidibirov and Dingwell, 1996). This notion of 'conduit clearing' corresponds with the timing and short-lived nature of the initial explosive pulse 
(Gouhier and Paris, 2019; Perttu et al., 2020; Prata et al., 2020), which is indistinguishable from the timing of the collapse itself.

The U10-3 and U10-4 deposits represent Phase B, with a sharp increase in $N_{A}$ and feldspar crystallinity, smaller mean microlite sizes, and various disequilibrium morphologies (i.e., acicular, hopper and swallowtail), implying nucleation-dominated crystallisation under high $\Delta \mathrm{T}$ (Lofgren, 1980; Hammer and Rutherford, 2002). Although U10-3 displays nucleation-dominated textures, its low ascent rate and aspect ratio (similar to U23-2/KRA-233) suggests that U10-3 records pre-collapse ascent and crystallisation conditions, overprinted by rapid decompression-induced crystallisation following the collapse. The switch to rapid degassing associated with open-system decompression of the conduit - marked by the low water contents of U10-3 - may explain the sharp change in crystal development, as $T_{\text {liquidus }}$ (and $\Delta T$ ) would have increased through both decompression and water loss (e.g., Cashman and Blundy, 2000). Decompression of a pressurised conduit, further unloaded by the initial blast of U23-2, may have facilitated the rapid acceleration of deeper magma (i.e. U10-3, then U10-4), evident from the increasing ascent rate. Higher pyroxene microlite proportions (Fig.4c and d) further support faster decompression rates (cf. decompression experiments in Szramek et al., 2006).

Nucleation-dominated crystallisation under high $\Delta \mathrm{T}$ persisted within Phase $\mathrm{C}$ (U10-8 and U10-10). However, these samples display decreased $\mathrm{N}_{\mathrm{A}}$ and feldspar crystallinity, and a slight increase in mean microlite size, consistent with a gradual re-stabilisation of the feeder system with reduced magma ascent velocities (with U10-6 representing the transition towards these conditions). While the absolute ascent and decompression rate values are subject to uncertainties (e.g., water content), the overall pattern from U232 and through the U10 sequence is systematic, reflecting disruption of ascent processes across a shorttimescale.

\subsection{Collapse effects on glass and feldspar compositions}

Groundmass glass compositions highlight subtle crystallisation changes spanning the collapse period. Using Rhyolite-MELTS, we modelled equilibrium crystallisation pathways during isothermal decompression (ITD) to constrain crystallisation conditions (Appendix 3). Late-stage melt evolution can be tracked within $\mathrm{MgO}-\mathrm{K}_{2} \mathrm{O}$ space; $\mathrm{MgO}$ represents a crystallisation fingerprint of mafic phases, and $\mathrm{K}_{2} \mathrm{O}$ tracks total crystallinity, assuming it behaves completely incompatibly (cf. Cashman and Edmonds, 2019).

Variable degrees of isobaric, deep mafic-phase crystallisation are implied by the initial lateral shifts in $\mathrm{MgO}$ values (Liu et al., 2020). Modelled pathways subsequently follow relatively steep gradients in $\mathrm{K}_{2} \mathrm{O}$, defining shallower isothermal decompression and decompression-induced plagioclase crystallisation (e.g., $\sim 80 \mathrm{MPa}$ at $1000^{\circ} \mathrm{C}$; Fig. 8). Glass compositions of KRA-233 and U23-2 (Phase A) are best characterised by the $1000{ }^{\circ} \mathrm{C}$ isotherm, while U10 glasses (Phase $\mathrm{B}+\mathrm{C}$ ) are shifted towards the $1050{ }^{\circ} \mathrm{C}$ isotherm (Fig.8). Higher melt temperatures for the U10 glasses imply a shorter duration of storage (i.e. reduced cooling) prior to decompression. However, cluster analysis depicts U10-3 as compositionally distinct from subsequent samples (U10-4 and U10-6), with low $\mathrm{Al}_{2} \mathrm{O}_{3} / \mathrm{Na}_{2} \mathrm{O}$ and high $\mathrm{FeO} / \mathrm{TiO}_{2}$ content (Fig.S6). Considering the mixed textural characteristics of U10-3, it implies that unloading disrupted this magma 
batch while stalling. Compositions of U10-4 and U10-6 then suggest temporarily reduced crystallisation (low $\mathrm{K}_{2} \mathrm{O}$, high $\mathrm{MgO}$ ), consistent with the faster and deeper decompression revealed by microlite textures. Glasses higher up the stratigraphy (U10-8 and U10-10; Phase $\mathrm{C}$ ) have slightly higher $\mathrm{K}_{2} \mathrm{O}$; reconciled with lower ascent rates, this suggests longer crystallisation times as the system progressively stabilised.

Plagioclase compositions are particularly sensitive to changes in temperature, water pressure $\left(P_{\mathrm{H} 2 \mathrm{O}}\right)$, and $\mathrm{H}_{2} \mathrm{O}$ content. $\mathrm{U} 10$ groundmass compositions (Phase $\mathrm{B}+\mathrm{C}$ ) extend to notably higher values (An67-79) than U23-2 (Phase A), with the more calcic populations suggesting relatively higher $P_{\mathrm{H} 2 \mathrm{O}}$ and temperatures (Fig.5a) (Couch et al., 2003). The bimodal U10 populations imply tapping and mixing of rapidly ascending magma from across a broad depth range (see Appendix 4 and Supplementary Table 3 for barometry estimates), although the main microlite population is comparable (An50-63) across all samples, indicating crystallisation consistently extended to shallow levels ( $<80 \mathrm{MPa}$; Fig.8). Plagioclase phenocryst rims and cores also exhibit a slight increase in An-content higher up the U10 stratigraphy (Fig.6a), consistent with a hotter and deeper origin.

\subsection{Fragmentation and magma-water interaction}

Ash morphological and surface characteristics in U23-2 and the U10 samples indicate variable fragmentation modes caused primarily by two brittle mechanisms. The vitric nature, fracture patterns and relatively high angularity of U23-2 (Fig. $2 \mathrm{~d}$ and e) are consistent with sudden decompression, driven by a downward propagating decompression wave, producing brittle fracture and relatively denser textures (Alidibirov and Dingwell, 1996). In U10, blocky and sub-angular morphologies, alongside stepped or riverline fractures on grain surfaces, also signify a dominant brittle fragmentation process. However, the overall
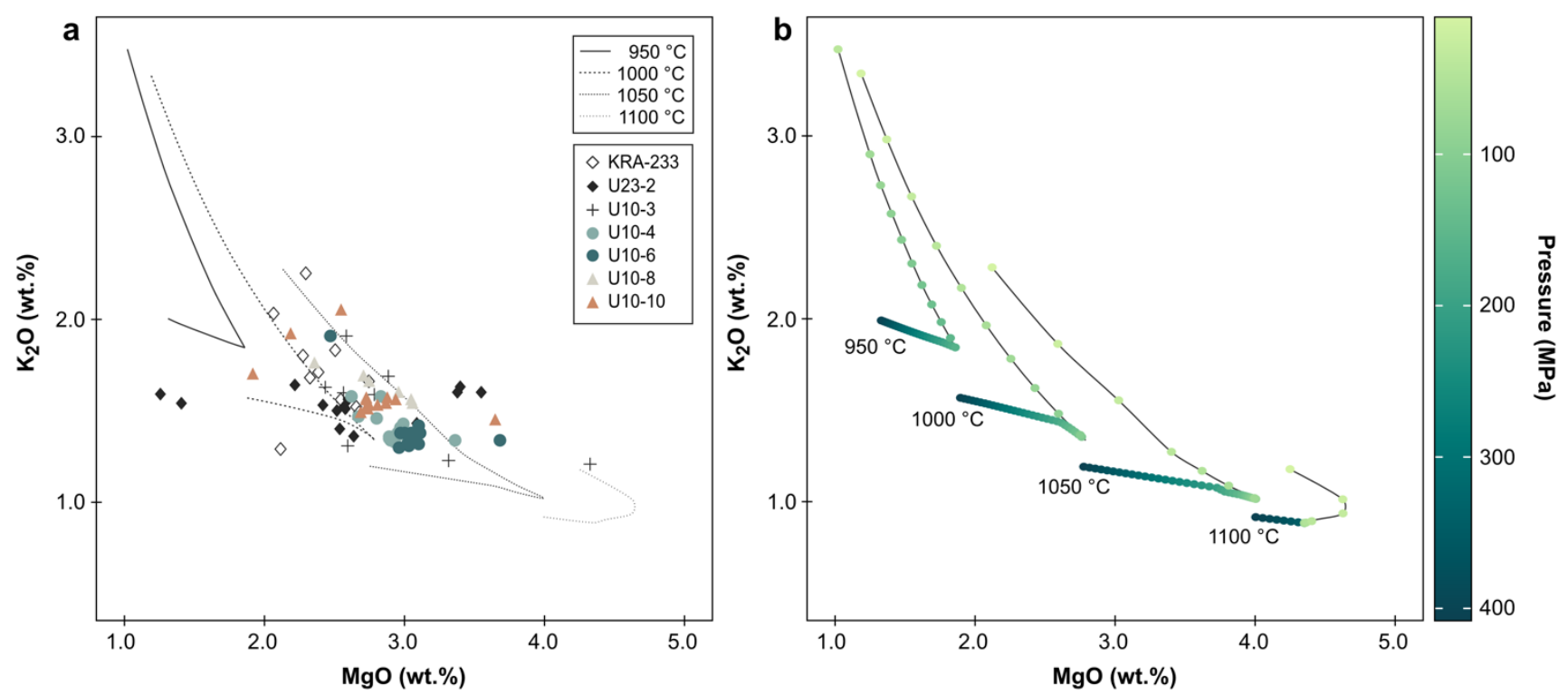

Figure 8

Rhyolite-MELTS models of crystallisation pathways highlighting the evolution of melt composition $\left(\mathrm{K}_{2} \mathrm{O}\right.$ vs. $\mathrm{MgO}$ ) during isothermal decompression. a Measured EPMA glass compositions are compared to modelled melt compositional pathways. Models were run using the average 2018 XRF bulk composition, $2.5 \mathrm{wt} . \% \mathrm{H}_{2} \mathrm{O}$, $\mathrm{fO}_{2}$ of nickel-nickel oxide (NNO), at temperatures between $950{ }^{\circ} \mathrm{C}$ and $1100{ }^{\circ} \mathrm{C}$ in $50{ }^{\circ} \mathrm{C}$ increments and decompression from 400 to $10 \mathrm{MPa}$. b Model runs displayed in a coloured according to pressure changes during isothermal decompression. 
increase in vesicularity, relative to U23-2 (Fig.3b and c), suggests this was driven by vesicle overpressure, facilitated by rapid ascent and extensive degassing (Cioni et al., 2014; Gouhier and Paris, 2019). Minor ductile features (i.e. Pele's hairs) also emphasise the melt's relatively low viscosity, exiting the vent at high velocity (Büttner et al., 2002).

Visual observations and infrasound signals indicate the onset of Surtseyan activity after the collapse (Perttu et al., 2020). Interaction with seawater, leading to further brittle (and ductile) fragmentation, may have overprinted the primary brittle mechanisms (cf. Liu et al., 2017), although we would expect this interaction to be limited in U23-2. Following the unloading-induced explosion of U23-2, the high lithic and altered-grain content in U10-3 (and NP2-2; Fig.S2), as well as its distinctive colour and bulk chemistry, suggests a vent widening stage (incorporating material from the crater walls). This would have enabled greater magma-water interaction increasing fragmentation efficiency, as implied by finer tails in the U10 grain-size distributions compared to U23-2 (Fig.1a). The collapse also uncovered the subsurface hydrothermal system on the SW flank, indicated by the orange seawater plumes evident in post-collapse satellite images (Fig.S1b).

\subsection{Reconstruction of syn- and post-collapse eruptive activity}

Anak Krakatau's collapse, at $\sim 20: 55$, immediately initiated decompression-driven brittle magma fragmentation in the shallow conduit. This magma had been feeding Strombolian eruptions and had ascended under conditions characteristic of the preceding months (Fig.9a). Unloading of the conduit elicited a highly explosive, short-lived eruption (Phase A), with rapid plume ascent reaching $\sim 16 \mathrm{~km}$ (Gouhier and Paris, 2019; Prata et al., 2020) (Fig.9b). This also led to elevated, open-system degassing, with SO2 output from 22 - 28 December estimated at $~ 98$ kt (Gouhier and Paris, 2019).

The eruption of hotter, deeper magmas (Phase B), rapidly ascending through the decompressed feeder system (evident from a shift towards rapid nucleation of smaller microlites), followed the initial explosion. Primary brittle fragmentation was driven by vesicle overpressure, as suggested by the increase in ascent rates and vesicularity. U10-3 defines the onset of extensive seawater interaction, with a vent widening stage leading to sustained Surtseyan activity, producing cock's tail jets and ash-laden, low-altitude plumes (Fig.9c) (Prata et al., 2020).

Magma ascent conditions gradually stabilised in response to pressure conditions that had been modified both by the collapse and then by the rapid island regrowth (Novellino et al., 2020) that accompanied the Surtseyan eruptions (Fig.9d; Phase C). Progressively lower magma ascent rates were accompanied by reduced degassing (rates falling by nearly $50 \%$ in late December, and $75 \%$ by early January 2019; Gouhier and Paris, 2019). Given the very rapid island growth ( $0.3 \mathrm{~km}^{3}$; cf. Hunt et al., 2021), we suggest that the system returned to equilibrium pressurisation conditions within a 1-2 week period as activity waned.

5.6. Implications for determining future collapse events and collapse impacts 
We have observed no evidence for unusual magma ascent patterns preceding the collapse, and the patterns observed in the post-collapse tephra-stratigraphy can be explained as a magmatic response to a collapse-driven pressure

perturbation of the feeder system. This implies that no distinctive pre-collapse magmatic signature (i.e., volcano seismicity, inflation or degassing) would have been apparent as a signal indicative of incipient collapse. However, progressive susceptibility of the SW flank to failure was evident from longer-term deformation and growth patterns. Lateral deformation of the SW flank was identified over ten years before the collapse (Agustan et al., 2012; Chaussard and Amelung, 2012), with evidence of an increase in the 2018 eruptive period (Walter et al., 2019). Since longer-term deformation datasets are limited, it is difficult to assess whether deformation rates in 2018 were substantially different to those during previous eruptions, or whether displacements showed an overall accelerating pattern. Nonetheless, longer-term patterns of Anak Krakatau's edifice growth reflect significant structural instabilities, ultimately related to the volcano's position on the scarp of the 1883 Krakatau caldera (Deplus et al., 1995), which led to asymmetrical tuff cone growth prior to 1960 , and restricted post-1960 lava delta emplacement to the SW half of the island (cf. Hunt et al., 2021). Following the cumulative loading of earlier eruptions, additional growth of the SW flank during the June-December 2018 activity is likely to have played a role in the timing of the collapse, potentially alongside increased pressurisation of the subsurface hydrothermal system

PRE-COLLAPSE 22 Dec. 18

SW

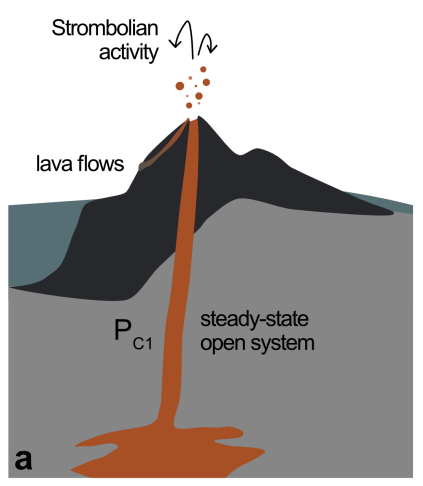

SYN-COLLAPSE: PHASE A 22 Dec. 18: 20:55

NE SW

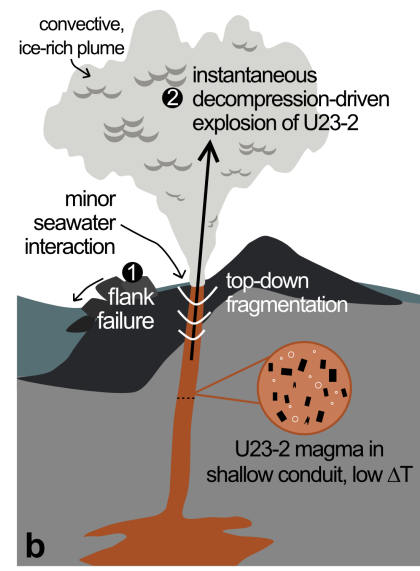

POST-COLLAPSE: PHASE B 22 Dec. 18: after $\sim 21: 35$ NE SW

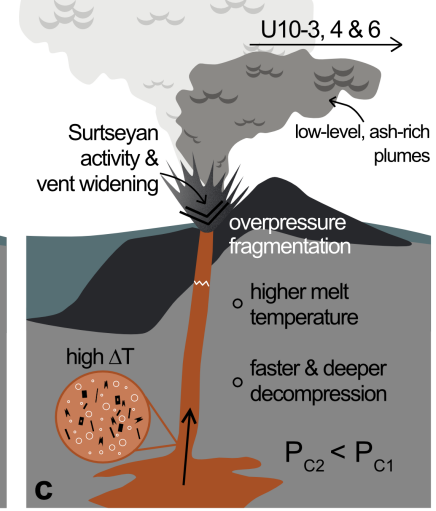

POST-COLLAPSE: PHASE C

Late Dec. 18

NE SW

NE

\section{Figure 9}

Conceptual model for syn- and post-collapse volcanic processes at Anak Krakatau from 22 Dec. 2018 to early Jan. 2019. a Pre-collapse: open, steady-state conditions, typical of the Strombolian feeder system reflected in low ascent velocities and microlite textures of KRA-233, U23-2 and U10-3. $P_{c 1}$ represents an average precollapse conduit pressure. b Phase A: lateral collapse and unloading causes downward propagating decompression within the surficial conduit, and the pressure perturbation induces an intense explosion. U232 magma experiences limited seawater interaction, and the dispersal of U23-2 tephra in the convective, icerich plume heads towards the SW. c Phase B: destabilisation, decompression and deeper tapping of the conduit facilitates fast ascent of U10-3 (Surtseyan vent widening) along with U10-4 and U10-6 (sustained Surtseyan activity). $P_{c 2}<P_{c 1}$ represents Phase $B$ with conditions of a highly depressurised conduit $\left(P_{c 2}\right)$ relative to the pre-collapse conduit pressure $\left(P_{c 1}\right)$. $\mathbf{d}$ Phase $C$ : system gradually re-stabilised with ascent characterised by lower velocities and decompression rates (U10-8 to U10-10). $P_{c 3}>P_{c 2}$ represents Phase $C$ conduit pressure re-stabilising following Phase $B$ eruptions and partial edifice regrowth. 
(e.g., Reid, 2004). Together, all these factors pre-conditioned the SW flank for its eventual collapse. For future monitoring of edifice stability at Anak Krakatau or elsewhere, an approach integrating short- and long-term edifice growth patterns with flank deformation monitoring (e.g., Gonzalez-Santana and Wauthier, 2020), and an improved understanding of edifice material properties (cf. Heap and Violay, 2021), may hold the best prospects for refining forecasts of collapse timing.

The Anak Krakatau collapse also reveals the impact of surface-unloading driven disruption on a shallow magmatic system. Although its volume was smaller than other historical collapses (e.g., Ritter Island; Karstens et al., 2019), sudden decompression led to a considerable magmatic response and readjustment, promoting highly elevated eruption rates. Decompression induced an abrupt, but subtle, glass compositional shift leading to the eruption of hotter, deeper melts (i.e., Phase B) that likely resulted from rapid and extensive volatile exsolution, favouring ascent through increased buoyancy. Such changes highlight the importance of edifice loading in modulating magma ascent and storage (cf. Watt, 2019). However, rapid edifice rebuilding may hinder opportunities to investigate such processes, by concealing failure scars and the stratigraphic record of collapse-associated volcanism.

\section{Conclusions}

Our physical, microtextural and geochemical analysis of syn- and post-collapse deposits shows no evidence that intrinsic magmatic changes preceded the lateral collapse of Anak Krakatau. Instead, the intense, accompanying volcanism is interpreted as a response to collapse-driven depressurisation of the magma system and can be divided into three main phases. Phase A involved a syn-collapse eruption triggered by decompression of the shallow conduit, generating a powerful explosive pulse and depositing ash to the SW. Textures in this ash record pre-collapse ascent conditions, excluding a direct magmatic trigger for edifice failure, suggesting the collapse resulted from longer-lived structural and gravitational instabilities arising from edifice development.

Phase B reflects successive post-collapse tapping of deeper, hotter magma batches from the depressurised conduit, with extensive degassing and accelerating ascent rates. Gradual re-stabilisation of conduit conditions occurred in Phase $\mathrm{C}$, as rapid edifice regrowth led to waning activity.

The 2018 collapse highlights that lateral collapses are not necessarily directly triggered by immediate shifts in magmatic behaviour. Therefore, effective volcanic monitoring and forecasting of such events may need to focus on identifying areas with increased susceptibility to failure, as signalled by changing edifice growth patterns and flank deformation; this will be particularly relevant for the future growth of Anak Krakatau.

\section{Acknowledgements}

We thank Alastair Hodgetts, Thomas Williams and Daniel Cox for help with sample preparation, Victoria Smith and Stuart Kearns for assistance with the electron microprobe, and Gren Turner for assistance with the SEM. This work was supported by NERC Grant NE/T002026/1 (SFLW, MC, SLE, MB). SFLW, SLE, DRT also acknowledge funding from NERC grant NE/S003509/1. MC acknowledges NERC fellowship NE/N014286/1. ALMN acknowledges NERC studentship NE/L202612/1. MA acknowledges MAIPARK Research Grant. CH acknowledges funding from NERC grant NE/S004106/1 
and COMET (https://comet.nerc.ac.uk/). JEH would like to acknowledge funding from NERC Grant NE/T002034/1. STG acknowledges support from NSF grant GEO-17-56665. We acknowledge NSF grant OCE-1555523 in the sharing of pre2018 Anak Krakatau samples. SLE, DRT and AN publish with the permission of the CEO, British Geological Survey. Finally, thank you to Katie Preece, Michihiko Nakamura, Lucia Gurioli, and one anonymous reviewer for their insightful and constructive comments.

\section{References}

1. Abdurrachman, M., Widiyantoro, S., Priadi, B. and Ismail, T., 2018. Geochemistry and Structure of Krakatoa Volcano in the Sunda Strait, Indonesia. Geosciences, 8(4), p.111.

2. Agustan, Kimata, F., Pamitro, Y.E. and Abidin, H.Z., 2012. Understanding the 2007-2008 eruption of Anak Krakatau Volcano by combining remote sensing technique and seismic data. International Journal of Applied Earth Observation and Geoinformation, 14(1), pp.73-82.

3. Alidibirov, M. and Dingwell, D.B., 1996. Magma fragmentation by rapid decompression. Nature, 380 (6570), pp.146-148.

4. Büttner, R., Dellino, P., La Volpe, L., Lorenz, V. and Zimanowski, B., 2002. Thermohydraulic explosions in phreatomagmatic eruptions as evidenced by the comparison between pyroclasts and products from Molten Fuel Coolant Interaction experiments. Journal of Geophysical Research: Solid Earth, 107(B11), pp.ECV-5.

5. Camus, G., Gourgaud, A. and Vincent, P.M., 1987. Petrologic evolution of Krakatau (Indonesia): implications for a future activity. Journal of Volcanology and Geothermal Research, 33(4), pp.299-316.

6. Cashman, K. and Blundy, J., 2000. Degassing and crystallization of ascending andesite and dacite. Philosophical Transactions of the Royal Society of London. Series A: Mathematical, Physical and Engineering Sciences, 358(1770), pp.1487-1513.

7. Cashman, K.V. and Edmonds, M., 2019. Mafic glass compositions: a record of magma storage conditions, mixing and ascent. Philosophical Transactions of the Royal Society A, 377(2139), p.20180004.

8. Chaussard, E. and Amelung, F., 2012. Precursory inflation of shallow magma reservoirs at west Sunda volcanoes detected by InSAR. Geophysical Research Letters, 39(21).

9. Cioni, R., Pistolesi, M., Bertagnini, A., Bonadonna, C., Hoskuldsson, A. and Scateni, B., 2014. Insights into the dynamics and evolution of the 2010 Eyjafjallajökull summit eruption (Iceland) provided by volcanic ash textures. Earth and Planetary Science Letters, 394, pp.111-123.

10. Couch, S., Harford, C.L., Sparks, R.S.J. and Carroll, M.R., 2003. Experimental constraints on the conditions of formation of highly calcic plagioclase microlites at the Soufriere Hills Volcano, Montserrat. Journal of Petrology, 44(8), pp.1455-1475.

11. Dahren, B., Troll, V.R., Andersson, U.B., Chadwick, J.P., Gardner, M.F., Jaxybulatov, K. and Koulakov, I., 2012. Magma plumbing beneath Anak Krakatau volcano, Indonesia: evidence for multiple magma storage regions. Contributions to Mineralogy and Petrology, 163(4), pp.631-651.

12. Deplus, C., Bonvalot, S., Dahrin, D., Diament, M., Harjono, H. and Dubois, J., 1995. Inner structure of the Krakatau volcanic complex (Indonesia) from gravity and bathymetry data. Journal of Volcanology and Geothermal Research, 64(1-2), pp.23-52.

13. D'Oriano, C., Bertagnini, A., Cioni, R. and Pompilio, M., 2014. Identifying recycled ash in basaltic eruptions. Scientific reports, 4(1), pp.1-8.

14. Gardner, M.F., Troll, V.R., Gamble, J.A., Gertisser, R., Hart, G.L., Ellam, R.M., Harris, C. and Wolff, J.A., 2013. Crustal differentiation processes at Krakatau volcano, Indonesia. Journal of Petrology, 54(1), pp.149-182.

15. Genareau, K., Wardman, J.B., Wilson, T.M., McNutt, S.R. and Izbekov, P., 2015. Lightning-induced volcanic spherules. Geology, 43(4), pp.319-322.

16. Gonzalez-Santana, J. and Wauthier, C., 2020. Unraveling long-term volcano flank instability at Pacaya Volcano, Guatemala, using satellite geodesy. Journal of Volcanology and Geothermal Research, p.107147.

17. Gouhier, M. and Paris, R., 2019. SO2 and tephra emissions during the 22 December, 2018 Anak Krakatau eruption. Volcanica, 2(2), pp.91-103.

18. Grilli, S.T., Tappin, D.R., Carey, S., Watt, S.F., Ward, S.N., Grilli, A.R., Engwell, S.L., Zhang, C., Kirby, J.T., Schambach, L. and Muin, M., 2019. Modelling of the tsunami from the 22 December, 2018 lateral collapse of Anak Krakatau volcano in the Sunda Straits, Indonesia. Scientific reports, 9(1), pp.1-13.

19. Hammer, J.E., Cashman, K.V. and Voight, B., 2000. Magmatic processes revealed by textural and compositional trends in Merapi dome lavas. Journal of Volcanology and Geothermal Research, 100(1-4), pp.165-192. 
20. Hammer, J.E. and Rutherford, M.J., 2002. An experimental study of the kinetics of decompression-induced crystallisation in silicic melt. Journal of Geophysical Research: Solid Earth, 107(B1). DOI: https://doi.org/10.1029/2001JB000281

21. Heap, M.J. and Violay, M.E., 2021. The mechanical behaviour and failure modes of volcanic rocks: a review. Bulletin of Volcanology, 83(5), pp.1-47.

22. Honour, V.C., Holness, M.B., Charlier, B., Piazolo, S.C., Namur, O., Prosa, T.J., Martin, I., Helz, R.T., Maclennan, J. and Jean, M.M., 2019. Compositional boundary layers trigger liquid unmixing in a basaltic crystal mush. Nature communications, 10(1), pp.1-8.

23. Hunt, J.E., Tappin, D.R., Watt, S.F.L., Susilohadi, S., Novellino, A., Ebmeier, S.K., Cassidy, M., Engwell, S.L., Grilli, S.T., Hanif, M., Priyanto, W.S., Clare, M.A., Abdurrachman, M. and Udrekh, U., 2021. Submarine landslide megablocks show half of Anak Krakatau island failed on December 22nd, 2018. Nature communications, 12(1), pp.1-15.

24. Hull, D., 1999. Fractography: observing, measuring and interpreting fracture surface topography. Cambridge University Press.

25. Karstens, J., Berndt, C., Urlaub, M., Watt, S.F., Micallef, A., Ray, M., Klaucke, I., Muff, S., Klaeschen, D., Kühn, M. and Roth, T., 2019. From gradual spreading to catastrophic collapse-Reconstruction of the 1888 Ritter Island volcanic sector collapse from high-resolution 3D seismic data. Earth and Planetary Science Letters, 517, pp.1-13.

26. Kirkpatrick, R.J., 1981. Kinetics of crystallization of igneous rocks. Reviews in Mineralogy 8, 321-398.

27. Liu, E.J., Cashman, K.V., Rust, A.C. and Gislason, S.R., 2015a. The role of bubbles in generating fine ash during hydromagmatic eruptions. Geology, 43(3), pp.239-242.

28. Liu, E.J., Cashman, K.V. and Rust, A.C., 2015b. Optimising shape analysis to quantify volcanic ash morphology. GeoResJ, 8, pp.14-30.

29. Liu, E.J., Cashman, K.V., Rust, A.C. and Höskuldsson, A., 2017. Contrasting mechanisms of magma fragmentation during coeval magmatic and hydromagmatic activity: the Hverfjall Fires fissure eruption, Iceland. Bulletin of Volcanology, 79(10), p.68.

30. Liu, E.J., Cashman, K.V., Miller, E., Moore, H., Edmonds, M., Kunz, B.E., Jenner, F. and Chigna, G., 2020. Petrologic monitoring at Volcán de Fuego, Guatemala. Journal of Volcanology and Geothermal Research, 405, p.107044.

31. Lofgren, G.,1980. Experimental studies on the dynamic crystallisation of silicate melts. Physics of magmatic processes, p.487-551.

32. Madden-Nadeau, A.L., Cassidy, M., Pyle, D.M., Mather, T.A., Watt, S.F.L., Engwell, S.L., Abdurrachman, M., Nurshal, M.E.M., Tappin, D.R. and Ismail, T., 2021. The magmatic and eruptive evolution of the 1883 calderaforming eruption of Krakatau: Integrating field-to crystal-scale observations. Journal of Volcanology and Geothermal Research, 411, p.107176.

33. McGuire, W.J., 2003. Volcano instability and lateral collapse. Revista, 1, pp.33-45.

34. Mollo, S. and Hammer, J.E., 2017. Dynamic crystallization in magmas. EMU Notes in Mineralogy, 16, pp.373418.

35. Murch, A.P. and Cole, P.D., 2019. Using microlites to gain insights into ascent conditions of differing styles of volcanism at Soufrière Hills Volcano. Journal of Volcanology and Geothermal Research, 384, pp.221-231.

36. Novellino, A., Engwell, S.L., Grebby, S., Day, S., Cassidy, M., Madden-Nadeau, A., Watt, S., Pyle, D., Abdurrachman, M., Edo Marshal Nurshal, M. and Tappin, D.R., 2020. Mapping recent shoreline changes spanning the lateral collapse of Anak Krakatau Volcano, Indonesia. Applied Sciences, 10(2), p.536.

37. Perttu, A., Caudron, C., Assink, J.D., Metz, D., Tailpied, D., Perttu, B., Hibert, C., Nurfiani, D., Pilger, C., Muzli, M. and Fee, D., 2020. Reconstruction of the 2018 tsunamigenic flank collapse and eruptive activity at Anak Krakatau based on eyewitness reports, seismo-acoustic and satellite observations. Earth and Planetary Science Letters, 541, p.116268.

38. Petrone, C.M., Braschi, E. and Francalanci, L., 2009. Understanding the collapse-eruption link at Stromboli, Italy: a microanalytical study on the products of the recent Secche di Lazzaro phreatomagmatic activity. Journal of Volcanology and Geothermal Research, 188(4), pp.315-332.

39. Pinel, V. and Jaupart, C., 2005. Some consequences of volcanic edifice destruction for eruption conditions. Journal of Volcanology and Geothermal Research, 145(1-2), pp.68-80.

40. Prata, A.T., Folch, A., Prata, A.J., Biondi, R., Brenot, H., Cimarelli, C., Corradini, S., Lapierre, J. and Costa, A., 2020. Anak Krakatau triggers volcanic freezer in the upper troposphere. Scientific reports, 10(1), pp.1-13.

41. Preece, K., Barclay, J., Gertisser, R. and Herd, R.A., 2013. Textural and micro-petrological variations in the eruptive products of the 2006 dome-forming eruption of Merapi volcano, Indonesia: implications for sub-surface processes. Journal of Volcanology and Geothermal Research, 261, pp.98-120.

42. Putirka, K.D., 2008. Thermometers and barometers for volcanic systems. Reviews in mineralogy and geochemistry, 69(1), pp.61-120. 
43. PVMBG (Pusat Vulkanologi dan Mitigasi Bencana Geologi). Activity reports for Anak Krakatau from 01/12/2018 03/01/2019, http://pvmbg.bgl.esdm.go.id/index.php/gunungapi/aktivitas-gunungapi (2018).

44. Reid, M.E., 2004. Massive collapse of volcano edifices triggered by hydrothermal pressurization. Geology, 32(5), pp.373-376.

45. Rosi, M., Levi, S.T., Pistolesi, M., Bertagnini, A., Brunelli, D., Cannavò, V., Di Renzoni, A., Ferranti, F., Renzulli, A. and Yoon, D., 2019. Geoarchaeological evidence of Middle-Age tsunamis at Stromboli and consequences for the tsunami hazard in the Southern Tyrrhenian Sea. Scientific reports, 9(1), pp.1-10.

46. Szramek, L., Gardner, J.E. and Larsen, J., 2006. Degassing and microlite crystallisation of basaltic andesite magma erupting at Arenal Volcano, Costa Rica. Journal of Volcanology and Geothermal Research, 157(1-3), pp.182-201.

47. Taddeucci, J., Pompilio, M. and Scarlato, P., 2004. Conduit processes during the July-August 2001 explosive activity of Mt. Etna (Italy): inferences from glass chemistry and crystal size distribution of ash particles. Journal of Volcanology and Geothermal Research, 137(1-3), pp.33-54.

48. Toramaru, A., Noguchi, S., Oyoshihara, S. and Tsune, A., 2008. MND (microlite number density) water exsolution rate meter. Journal of Volcanology and Geothermal Research, 175(1-2), pp.156-167.

49. Walter, T.R., Haghighi, M.H., Schneider, F.M., Coppola, D., Motagh, M., Saul, J., Babeyko, A., Dahm, T., Troll, V.R., Tilmann, F. and Heimann, S., 2019. Complex hazard cascade culminating in the Anak Krakatau sector collapse. Nature communications, 10(1), pp.1-11.

50. Waters, L.E. and Lange, R.A., 2015. An updated calibration of the plagioclase-liquid hygrometer-thermometer applicable to basalts through rhyolites. American Mineralogist, 100(10), pp.2172-2184.

51. Watt, S.F.L., Karstens, J., Micallef, A., Berndt, C., Urlaub, M., Ray, M., Desai, A., Sammartini, M., Klaucke, I., Böttner, C. and Day, S., 2019. From catastrophic collapse to multi-phase deposition: flow transformation, seafloor interaction and triggered eruption following a volcanic-island landslide. Earth and Planetary Science Letters, 517, pp.135-147.

52. Watt, S.F.L., 2019. The evolution of volcanic systems following sector collapse. Journal of Volcanology and Geothermal Research, 384, pp. 280-303.

53. Wieser, P., Petrelli, M., Lubbers, J., Wieser, E., Kent, A., Till, C., 2021. Thermobar: A critical evaluation of mineral-melt thermobarometry and hygrometry in arc magmas using a new open-source Python3 tool. GSA connects 2021. Portland.

54. Wohletz, K.H., 1983. Mechanisms of hydrovolcanic pyroclast formation: grain-size, scanning electron microscopy, and experimental studies. Journal of Volcanology and Geothermal Research, 17(1-4), pp.31-63.

55. Ye, L., Kanamori, H., Rivera, L., Lay, T., Zhou, Y., Sianipar, D. and Satake, K., 2020. The 22 December 2018 tsunami from flank collapse of Anak Krakatau volcano during eruption. Science Advances, 6(3), p.1377. 


\section{Supplementary Materials for...}

'Downward-propagating eruption following vent unloading implies no direct magmatic trigger for the 2018 lateral collapse of Anak Krakatau'

○ Supplementary Table 1: Sample list with location and analytical details, summary of exterior ash grain component types (evaluated on $500 \mu \mathrm{m}$ to $1 \mathrm{~mm}$ sieved size fraction) \& summary of interior grain texture types (evaluated across three grain sizes: 63-125 $\mu \mathrm{m}, 125-180 \mu \mathrm{m}$ and 180-250 $\mu \mathrm{m})$. See separate .x/sx spreadsheet.

○ Supplementary Table 2: Compositional analyses (XRF \& EMPA) for Anak Krakatau 2018 and 1997 tephra samples. See separate .xlsx spreadsheet.

- Supplementary Table 3: Temperatures and pressures calculated using thermobarometers of plagioclase and orthopyroxene from (Putirka, 2008) in the Python3 tool Thermobar (Wieser et al. 2021). See separate .xlsx spreadsheet.

○ Appendix 1: Analytical methods (p.2-4)

- Appendix 2: Interior ash grain textures (p.5)

○ Appendix 3: Rhyolite-MELTS modelling (p.6)

○ Appendix 4: Thermobarometry estimates (p.7)

○ Supplementary Figures S1 to S8 (p.8-16)

○ References (p.17-18) 


\section{Appendix 1: Analytical methods}

\subsection{Physical characterisation of tephra}

Grain size distribution of all samples was measured by wet sieving at half-phi intervals and using laser diffraction analysis (Malvern Mastersizer 2000), and both methods were applied to all samples. The grain size characteristics were determined using Gradistat V.8.0 (Blott and Pye, 2001) with the Folk and Ward (1957) parameters. Componentry was carried out on 200 grains from selected sample populations (Supplementary Table 1) in the $0-1 \phi(500 \mu \mathrm{m}-1 \mathrm{~mm})$ size fraction.

\subsection{Morphological analysis}

Grain size fractions $2 \phi-2.47 \phi(250-180 \mu \mathrm{m}), 2.47 \phi-3 \phi(180-125 \mu \mathrm{m})$ and $3 \phi-4 \phi(125-63$ $\mu \mathrm{m})$ were mounted on carbon adhesive-coated aluminium stubs and gold-coated for secondary electron (SE) imaging. SE images of grain exterior surfaces were acquired using the Phenom ProX scanning electron microscope (SEM) at the University of Birmingham. Operating conditions included an accelerating voltage of $15 \mathrm{kV}$ with a working distance of $10 \mathrm{~mm}$ and magnifications ranging between 275 and $800 \times$.

The same grain size fractions were also prepared as carbon-coated polished resin grain mounts for back-scattered electron (BSE) imaging for morphological analysis. Different size fractions were used to assess variation in ash-grain shape as a function of size (Liu et al. 2015a). BSE images were taken with the FEI Quanta 600 ESEM at the British Geological Survey (BGS), Keyworth. BSE mosaic images were obtained manually using a $20-\mathrm{kV}$ accelerating voltage with a working distance of $10 \mathrm{~mm}$. Images were acquired at a resolution of $1024 \times 884$ using a $200 \times$ magnification. Each overall mosaic image was digitally stitched together, containing between 15 and 32 individual images. 2D shape analysis was conducted by first processing the SEM images, after Liu et al. (2015a), using ImageJ software (https://imagej.nih.gov/ij/index.html). Using Liu et al.'s (2015b) ImageJ macro, ash shape outlines were measured using the convexity index $(\mathrm{Cl})$ and axial ratio (AR) shape parameters (Liu et al. 2015a).

\subsection{Geochemical Analysis}


X-ray fluorescence (XRF) was conducted for bulk-rock major and trace element compositions using a PANalytical Axios Advanced spectrometer at the University of Leicester. Major and trace elements were measured on glass beads fused from ignited powders and pressed powder pellets, respectively. Results are stated as component oxide weight percent and recalculated to include loss on ignition (LOI), which was separately determined.

Compositions of groundmass glass in vesicular microlite-rich and microlite-poor grains were analysed using the JEOL JXA-8600 wavelength-dispersive electron probe microanalyser (EPMA) at the Research Laboratory for Archaeology and the History of Art, University of Oxford, and mineral compositions using the Cameca SX100 EPMA at the University of Bristol. Glass compositions were acquired using a $15 \mathrm{kV}$ accelerating voltage, $8 \mathrm{nA}$ beam current, and $10 \mu \mathrm{m}$ beam diameter; crystal analyses used a $20 \mathrm{kV}$ accelerating voltage, $20 \mathrm{nA}$ beam current and $1 \mu \mathrm{m}$ spot size. Sodium was analysed first to minimise alkali migration. Primary mineral standards were used to calibrate in both cases, and Max Planck Institute reference glasses were used as secondary standards in glass analyses to verify calibration (Jochum et al., 2006); the averaged values of these had standard deviations $<0.80$ of the preferred values (Jochum et al., 2006). Full compositional data for bulk rock, glass and crystal phases are provided in Supplementary Table 2.

We applied a hierarchical cluster analysis (using the Euclidean distance measure and Ward's agglomerative clustering algorithm of minimum variance; Ward, 1963) using the $R$ software ( $R$ Core Team, 2013) to explore variation among glass data of pre-, syn- and post-collapse tephra units. The samples were clustered based on their average oxide compositions $\left(\mathrm{SiO}_{2}, \mathrm{TiO}_{2}, \mathrm{Al}_{2} \mathrm{O}_{3}\right.$, $\mathrm{FeO}, \mathrm{MgO}, \mathrm{CaO}, \mathrm{Na}_{2} \mathrm{O}$ and $\mathrm{K}_{2} \mathrm{O}$; all normalised to $100 \%$ anhydrous). Concentrations were first normalised to their z-scores prior to cluster analysis, to prevent abundant major elements from dominating the clustering.

\subsection{D microlite analysis}

Dark vesicular, microlite-rich grains from the 1-0 $\phi(500 \mu \mathrm{m}-1 \mathrm{~mm})$ size fraction were randomly chosen from selected samples (Supplementary Table 1) (one or two ash grains per sample) for 2D microlite analysis. Although vesicular, microlite-poor ash grains represent a large majority of 
samples (see Appendix 2), these grains could not be used for detailed microlite analysis as there is an insufficient number of microlites available per ash grain. The grains were prepared as carboncoated polished grain mounts and analysed in back-scattered electron (BSE) mode using the FEI Quanta 600 ESEM at the BGS. An accelerating voltage of $20 \mathrm{kV}$ and a $10 \mathrm{~mm}$ working distance at $\sim 900 \mathrm{x}$ magnification was used to obtain images. At least $\sim 400$ plagioclase feldspar microlites in each sample were manually outlined in BSE groundmass images using Affinity Designer (https://affinity.serif.com/en-gb/designer/).

Measurements including the field of view area, individual crystal area, crystal dimensions (using the fit ellipse option), and the number of crystals were conducted in Image J from binary-converted outlined BSE images. Microlites that intersected the image edges were not considered. For plagioclase, area fraction ( $\varphi=$ total area of feldspar crystals/total area of groundmass), mean aspect ratio (major/minor axis of crystals), and area number densities $\mathrm{N}_{a}$ (number of crystals per $\mathrm{mm}^{2}$ ) were calculated (Hammer et al., 2000) from initial ImageJ measurements. The representative plagioclase crystal size, $S_{n}\left(\mu m\right.$; Eq.1), and volumetric plagioclase number density, $N_{v}$ (number of crystals/mm³; Eq.2), were also calculated (Cashman, 1992).

$$
\begin{aligned}
& S_{n}=\left(\frac{\phi}{N_{a}}\right)^{0.5} \\
& N_{v}=\frac{N_{a}}{S_{n}}
\end{aligned}
$$




\section{Appendix 2: Interior ash grain textures}

Additional componentry based on variation of interior grain textures was undertaken on the same BSE mosaic images used for morphology. All component data is presented in Supplementary Table 1. Ash grains were categorised into five main groups based mainly on bubble and crystal texture: (1) vesicular, (2) dense, (3) free crystals, (4) holocrystalline and (5) glass shards. Further subdivisions of vesicular and dense grains were made based on the degree of groundmass present (Fig.S7 and Fig.S8). Vesicular grains are moderately to highly vesicular with irregular vesicles, and can contain numerous small microlites $(>50 \%)$ or few microlites $(<50 \%)$ within a glassy matrix. Vesicle morphologies within grains vary depending on crystallinity. Microlitepoor grains typically exhibit smaller, spherical, and isolated vesicles, whereas microlite-rich grains contain irregular and coalesced vesicles. Dense grains are blocky and poorly vesicular with a variable microcrystalline texture (similar to vesicular grains mentioned above) in a glassy matrix. Free crystals are either whole or fragments of feldspar and pyroxene crystals. Holocrystalline grains are fully crystallised, which may represent recycled grains or parts eroded from the conduit. Glass shards are broken fragments of the glassy matrix, marked by highly concave outlines (c.f. Liu et al., 2015a).

Between different grain size fractions, the most significant trends are associated with the vesicular grains (including glass shards) and dense grains (including free crystals and holocrystalline grains). The proportion of vesicular grains increases with larger grain size fractions, whereas the proportion of dense grains decreases with larger grain size fractions. Both trends are broadly consistent with the ash morphology results (see Section 4.3). U10-4 also displays a higher proportion of microlite-poor ash grains, which corresponds with its low $\mathrm{K}_{2} \mathrm{O}$ contents from glass data. 


\section{Appendix 3: Rhyolite-MELTS modelling}

We modelled equilibrium crystallisation pathways (cf. Cashman and Edmonds, 2019) using Rhyolite-MELTS (Gualda and Ghiorso, 2015) to constrain the conditions modulating the glass data variation observed. Following the method of Liu et al. (2020), we produced crystallisation paths by isothermal decompression (ITD) (pressure: 400-10 MPa in $10 \mathrm{MPa}$ increments; temperature: 950 ${ }^{\circ} \mathrm{C}, 1000^{\circ} \mathrm{C}, 1050^{\circ} \mathrm{C}$ and $1100^{\circ} \mathrm{C}$ ) using our average $2018 \mathrm{XRF}$ bulk composition (Supplementary Table 2), differing $\mathrm{H}_{2} \mathrm{O}$ contents (2.5-4.0 wt.\%), and a nickel-nickel oxide (NNO) buffer. Only the model with 2.5 wt. $\% \mathrm{H}_{2} \mathrm{O}$ content is shown in the main text (Fig. 8), as changes to initial water content or redox buffer do not affect the crystallisation paths considerably (Liu et al., 2020). 


\section{Appendix 4: Thermobarometry estimates}

To constrain pre-eruptive magmatic temperatures and crystallisation pressures, we used the plagioclase- and orthopyroxene-melt thermobarometers of Putirka (2008). Temperature and pressure estimates were both iteratively calculated in the Python3 tool Thermobar (v.0.0.9; Wieser et al., 2021) using phenocryst rims and average matrix glass compositions (Supplementary Table $3)$.

Considering the KD crystal-melt equilibrium criterion of Putirka (2008) (plagioclase, $K_{D}(A b-$ $\mathrm{An})^{\text {plag-liq }}=0.28 \pm 0.11$ if temperature is $>1050^{\circ} \mathrm{C}$ or $\mathrm{K}_{\mathrm{D}}(\mathrm{Ab}-\mathrm{An})^{\text {plag-liq }}=0.10 \pm 0.05$ if temperature is $<1050^{\circ} \mathrm{C}$; orthopyroxene, $\left.\mathrm{K}_{\mathrm{D}}(\mathrm{Fe}-\mathrm{Mg})^{\text {opx-liq }}=0.29 \pm 0.06\right)$, many phenocryst rim compositions fail to meet the threshold. However, from the limited dataset $(n=19)$, plagioclase and orthopyroxene crystallisation temperatures were estimated using equations 23 and 28a of Putirka (2008), respectively. The plagioclase-melt thermometer yields values ranging between $1040-1058{ }^{\circ} \mathrm{C}( \pm$ $43^{\circ} \mathrm{C}$ uncertainty) for all samples, and the orthopyroxene-melt thermometer gives slightly higher estimates of $1058-1127^{\circ} \mathrm{C}\left( \pm 27^{\circ} \mathrm{C}\right.$ uncertainty $)$.

We derived barometry estimates using equation 25a for plagioclase and equation 29a for orthopyroxene (Putirka, 2008), and pressures range between $\sim 26-236 \mathrm{MPa}$ for plagioclase and 55-677 MPa for orthopyroxene. Calculated crystallisation depths (using densities 2320-2950 kg $\mathrm{m}^{-3}$; Kopp et al., 2001) are very broadly consistent with previous upper crustal estimates (c.f. Dahren et al., 2012), indicating two main storage levels of $\sim 3-6 \mathrm{~km}$ (plagioclase) and $\sim 15-20 \mathrm{~km}$ (orthopyroxene). However, caution should be taken with these estimates, as the errors associated with both barometer equations, $25 \mathrm{a}$ and $29 \mathrm{a}$, are significant $( \pm 380 \mathrm{MPa}$ and $\pm 210 \mathrm{MPa}$, respectively). 


\section{Supplementary figures}

a

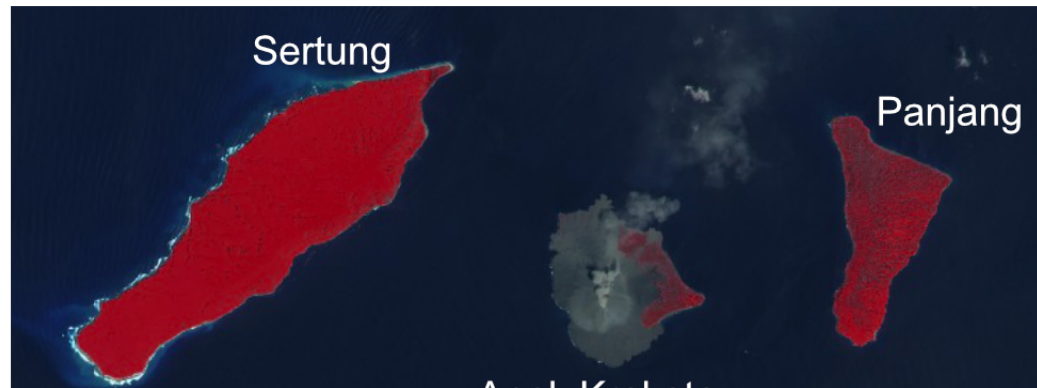

Anak Krakatau

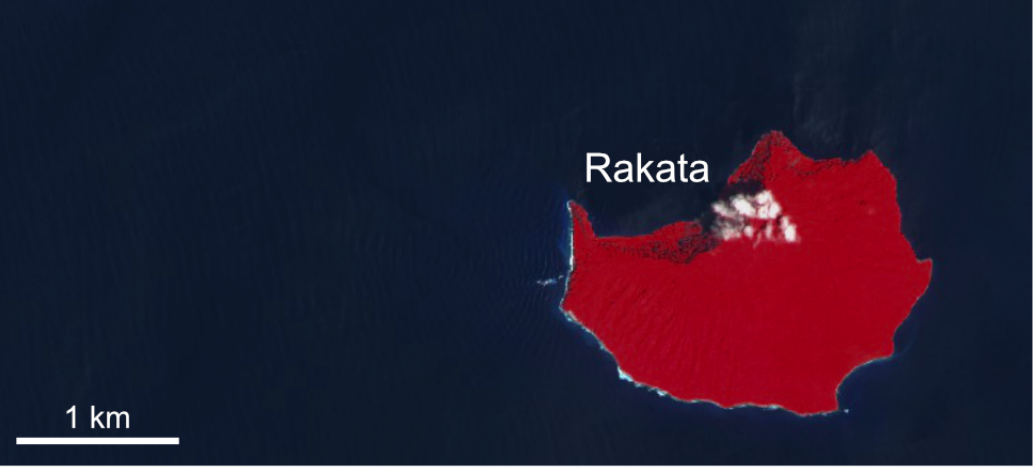

b

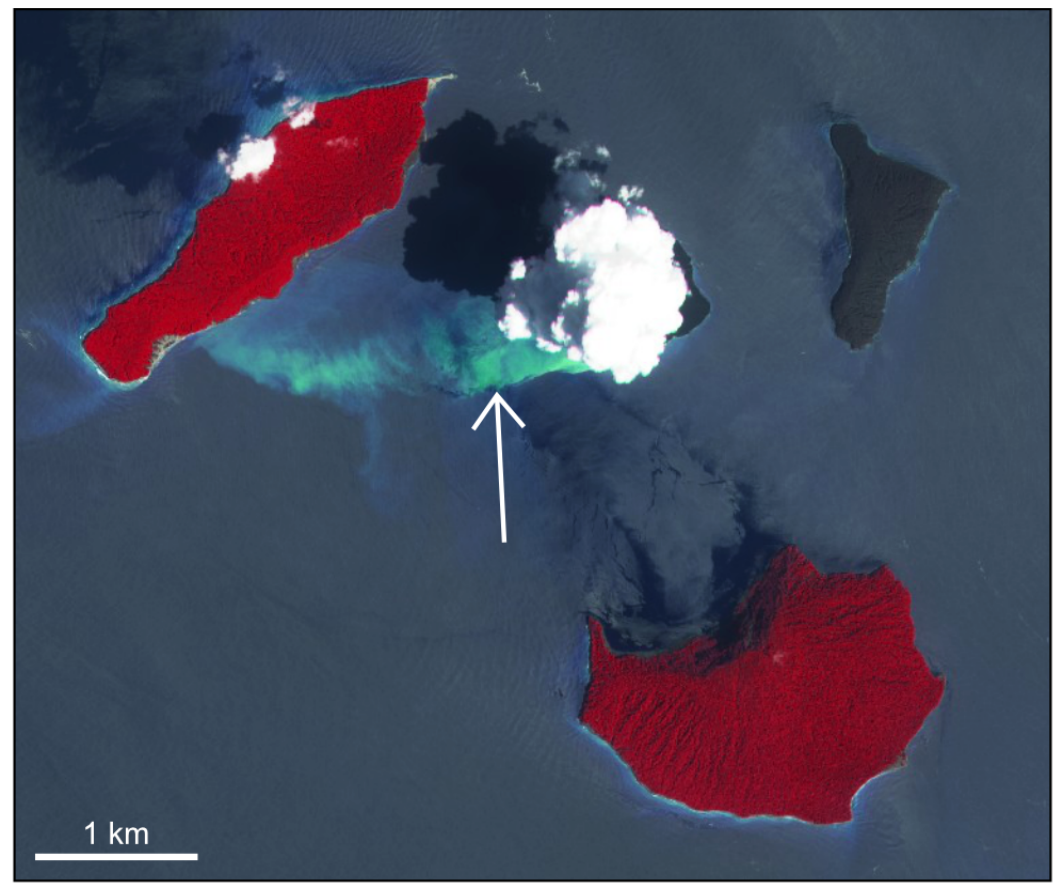

Figure S1: Sentinel 2 L1C satellite images of the Krakatau archipelago in infrared based on bands 8, 4 \& 3. Dense vegetation is highlighted in red and tephra deposition is shown in dark grey. a Pre-collapse image showing extensive fresh ash deposition/lava emplacement on Anak Krakatau and potential minor deposition on Panjang taken on 16 Nov. 2018. b Post-collapse image of significant ash deposition and vegetation loss on Anak Krakatau and Panjang (image taken on 10 Jan. 2019). White arrow highlights plume of reddish-orange (infrared = turquoise) water emanating from uncovered hydrothermal system off the SW island coastline. 

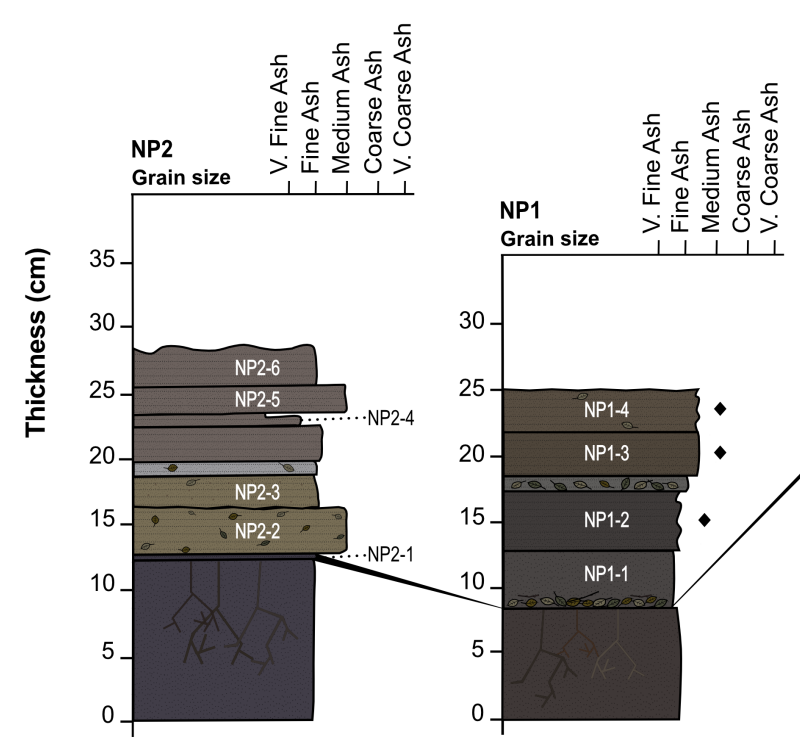

$3.94 \mathrm{~km}$ (Panjang)

$4.02 \mathrm{~km}$ (Panjang)

Distance from Anak Krakatau vent

b

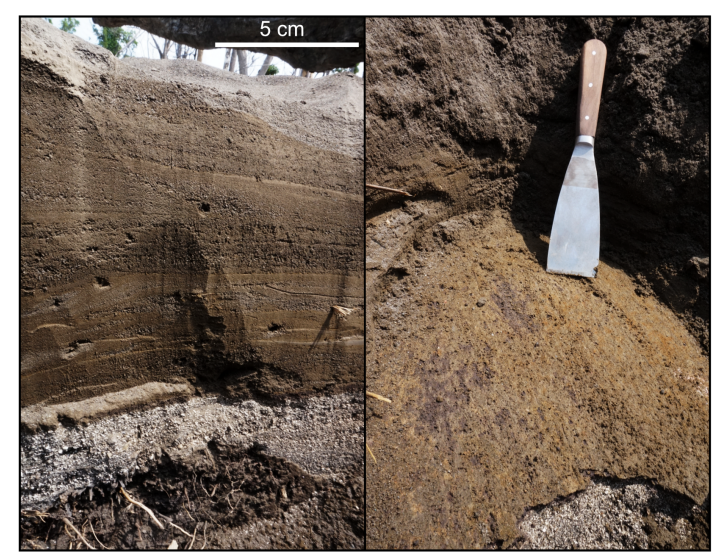

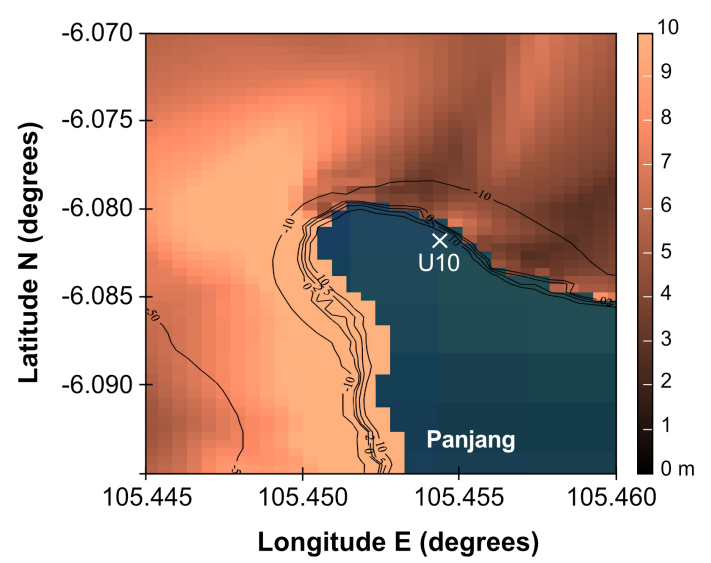

Figure S2: Dec. 2018 stratigraphies on Panjang (P) and Sertung (S). Black background shading indicates the only well-correlated layer (U10-3 and NP2-1) throughout the sections based on lithological characteristics (i.e., $0.5 \mathrm{~cm}$-thick layer of purple indurated ash; see right-hand side image in b). Colours and grain-size are based on field descriptions. White triangles mark samples analysed texturally and black diamonds mark samples analysed geochemically (XRF and/or EPMA). b Left image: close-up of U10 sequence. Right image: close-up of layer U10-3 showing the yellow oxidised crust at the surface of a purple indurated ash immediately overlying the pumiceous tsunami deposit (U10-2). c Tsunami simulation at $\sim 380$ s displaying maximum envelope for tsunami wave inundation at site U10 ( $~ 7 \mathrm{~m}$ wave height). Simulation used the 2D FUNWAVE model at $50 \mathrm{~m}$ resolution (Grilli et al., 2021). 

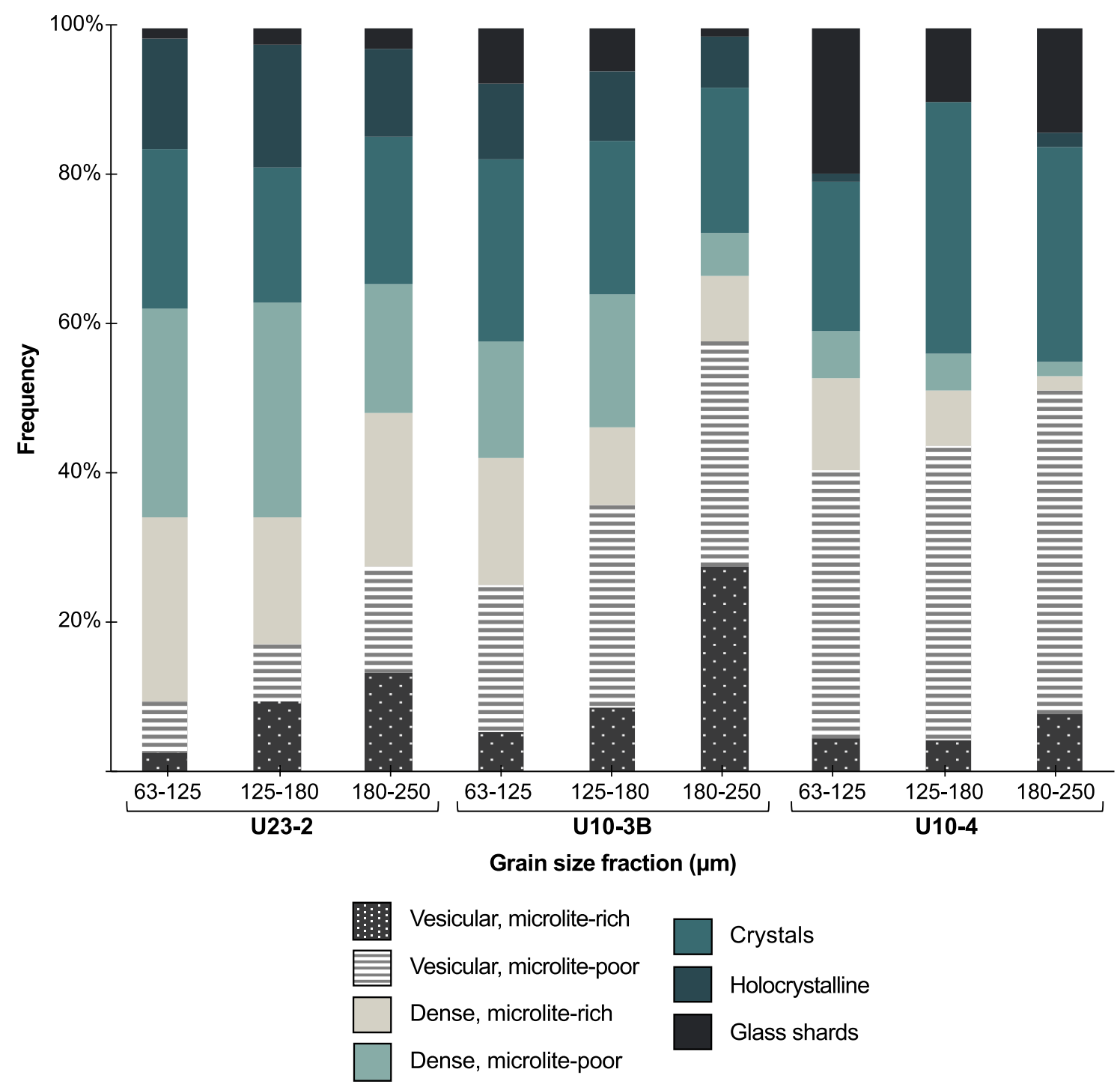

Figure S3: Component analysis of interior textures of ash grains (samples: U23-2, U10-3B and U10-4) using backscattered-electron SEM images. 

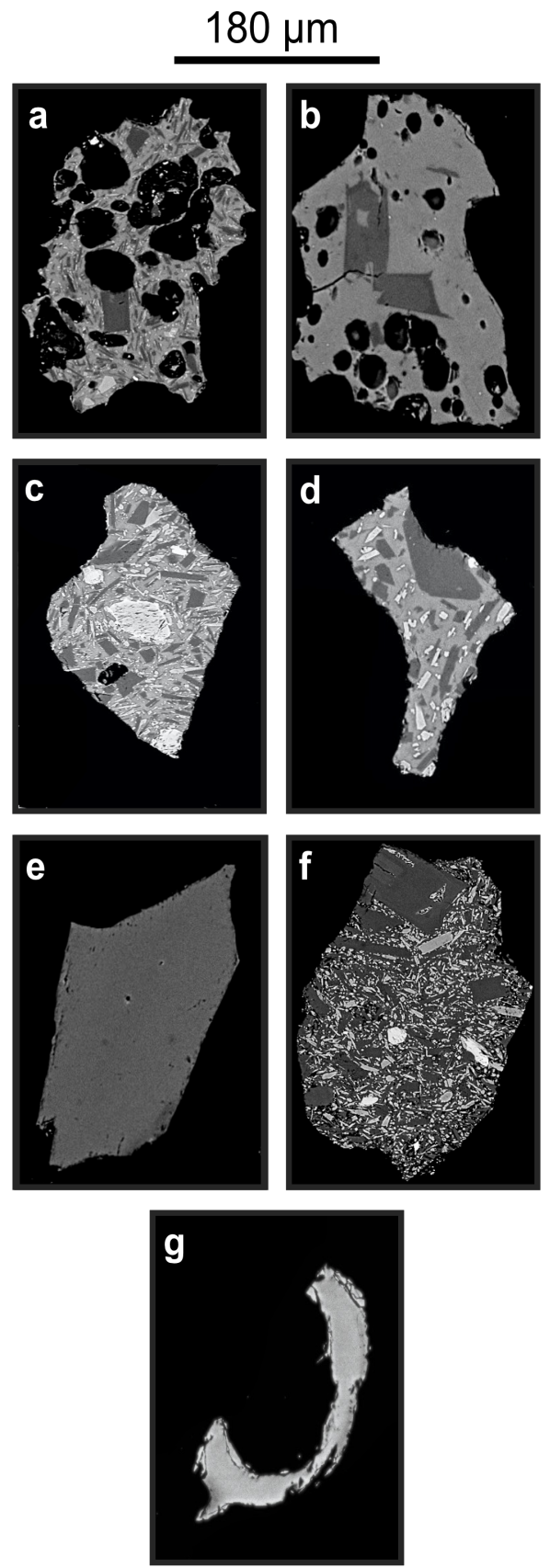

Figure S4: Representative BSE SEM images of each ash grain texture type (a, vesicular, microliterich; b, vesicular, microlite-poor; c, dense, microlite-rich; d, dense, microlite-poor; e, crystal; f, holocrystalline; $\mathbf{g}$, glass shard). 


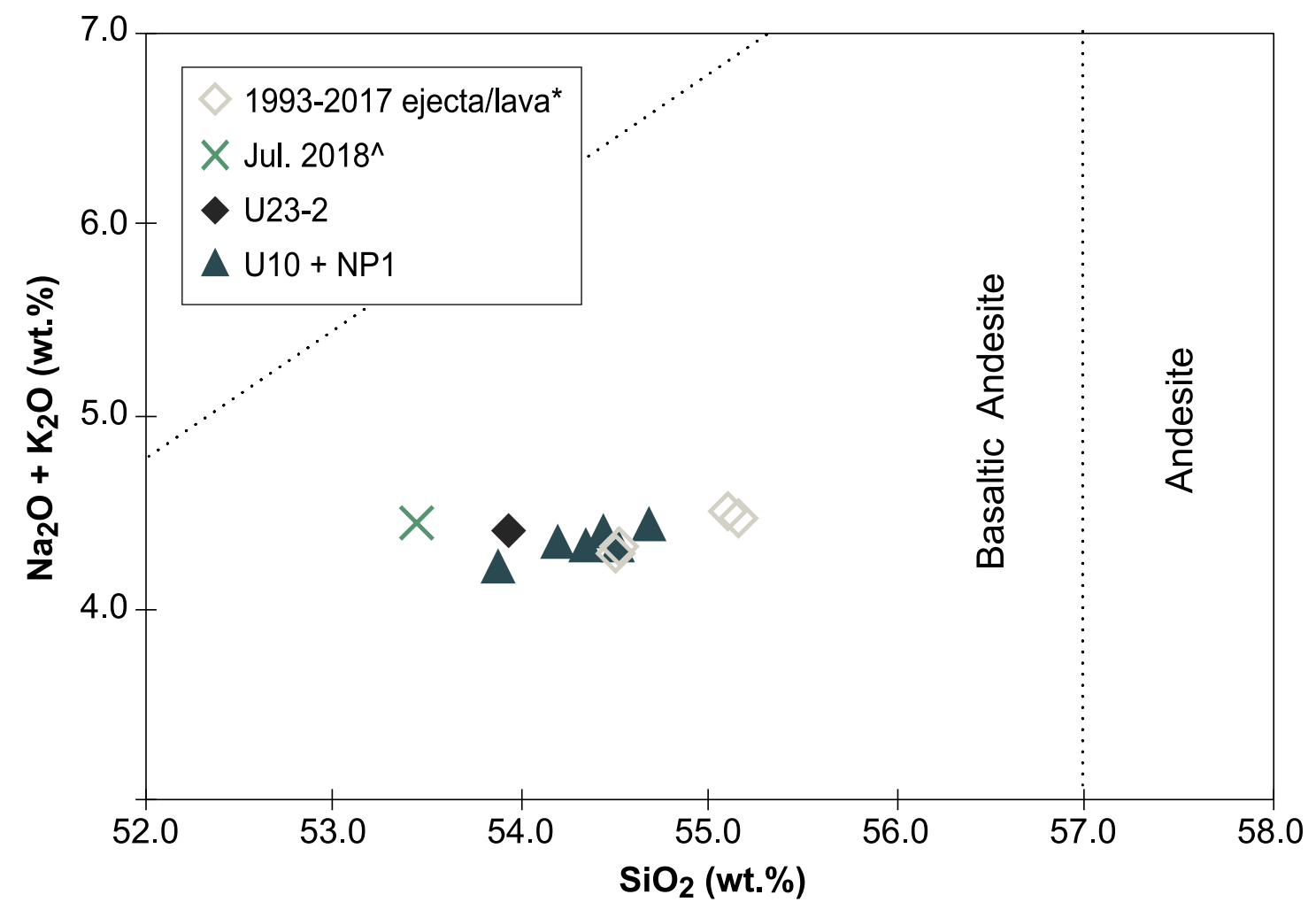

Figure S5: Whole-rock total alkali vs. silica (TAS) diagram of 2018 products (U23-2, U10, NP1), plotted alongside previously published data of other recent eruptive products ( ${ }^{\wedge}$ Walter et al. 2019; *includes data from Gardner et al. 2013). 
KRA-233

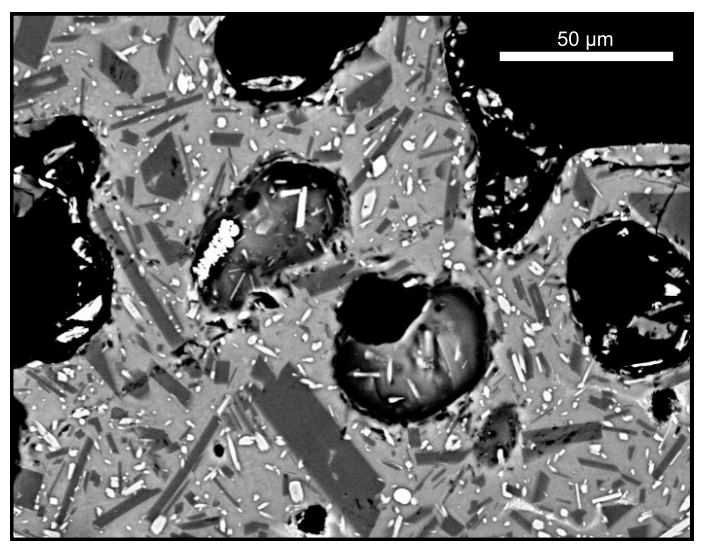

U23-2

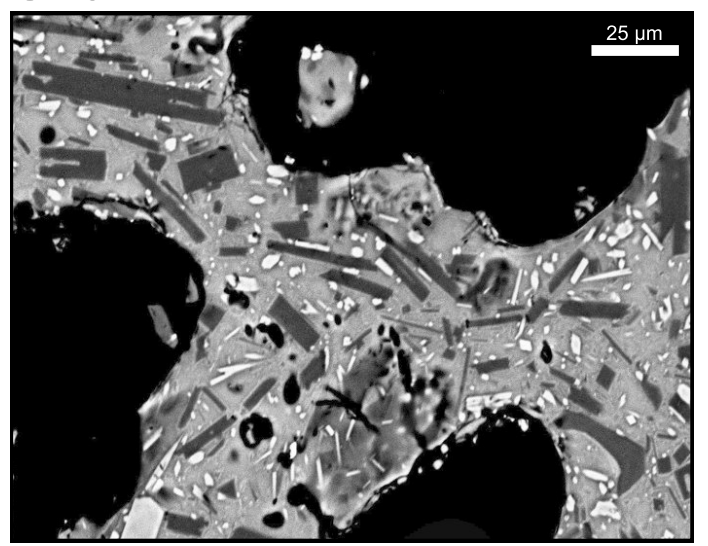

U10-3B

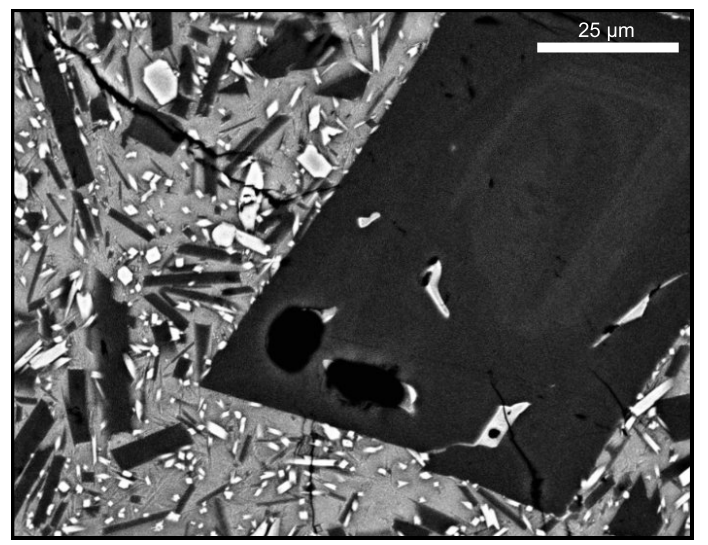

U10-4

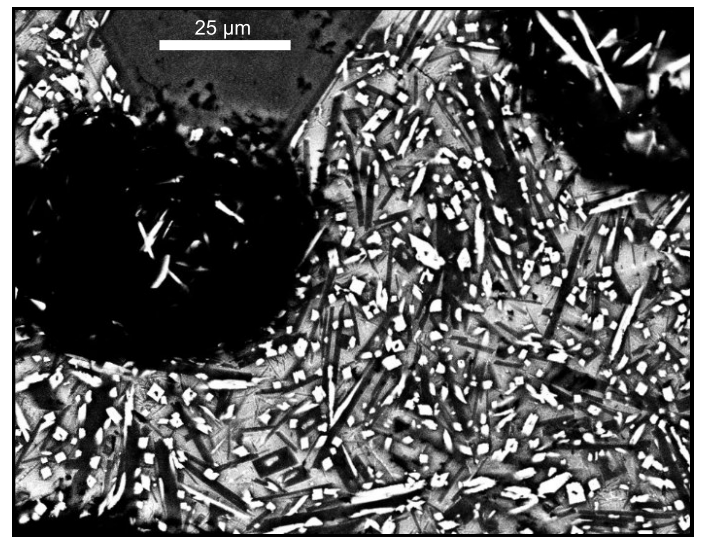

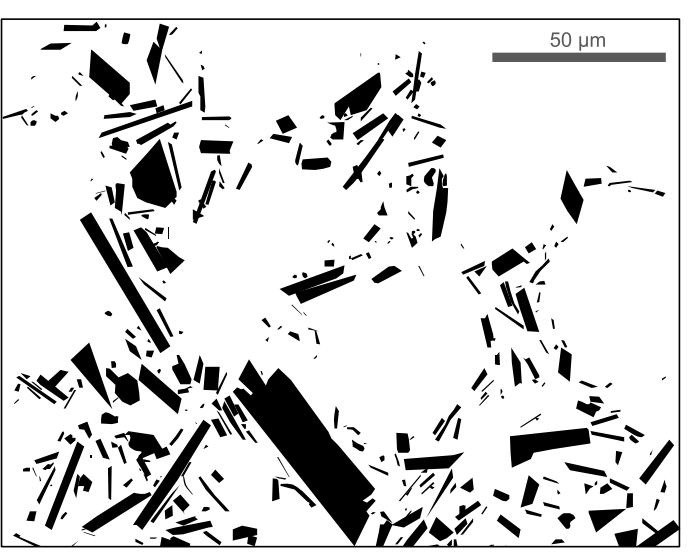
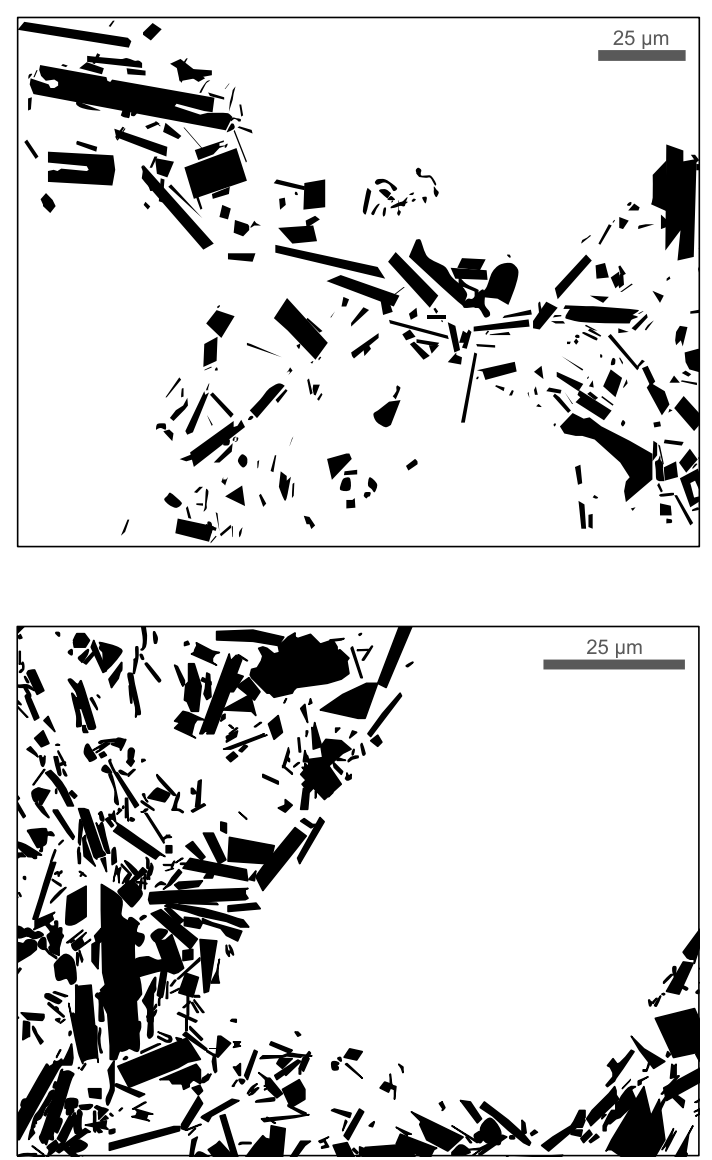


\section{U10-6_2}
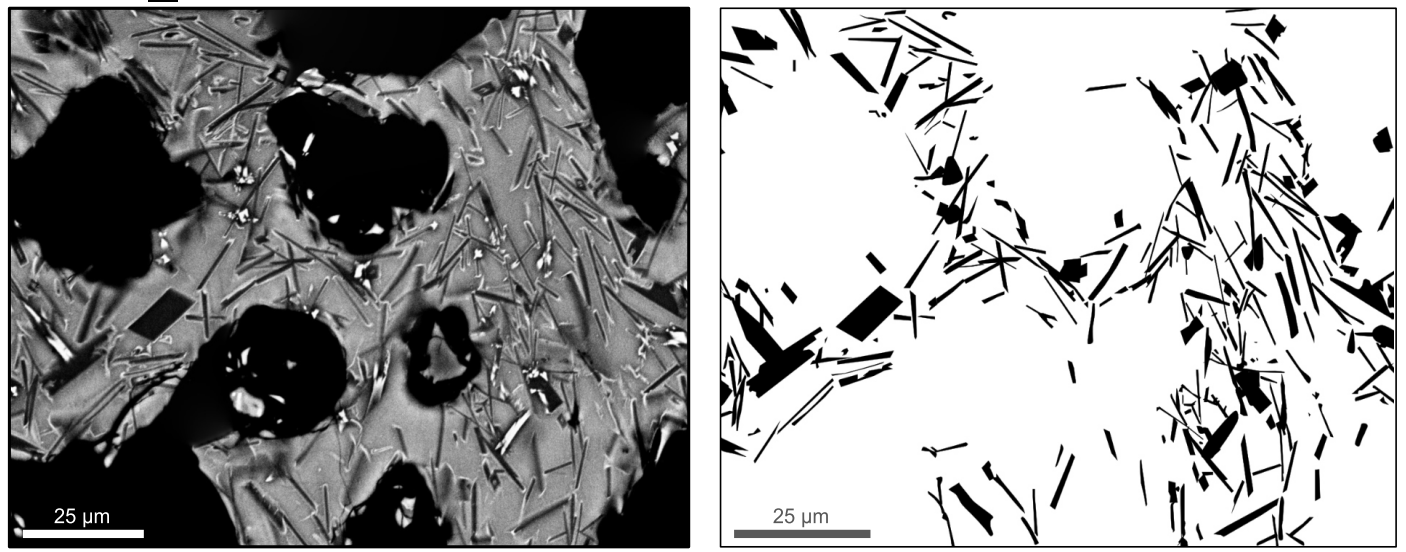

U10-8 1
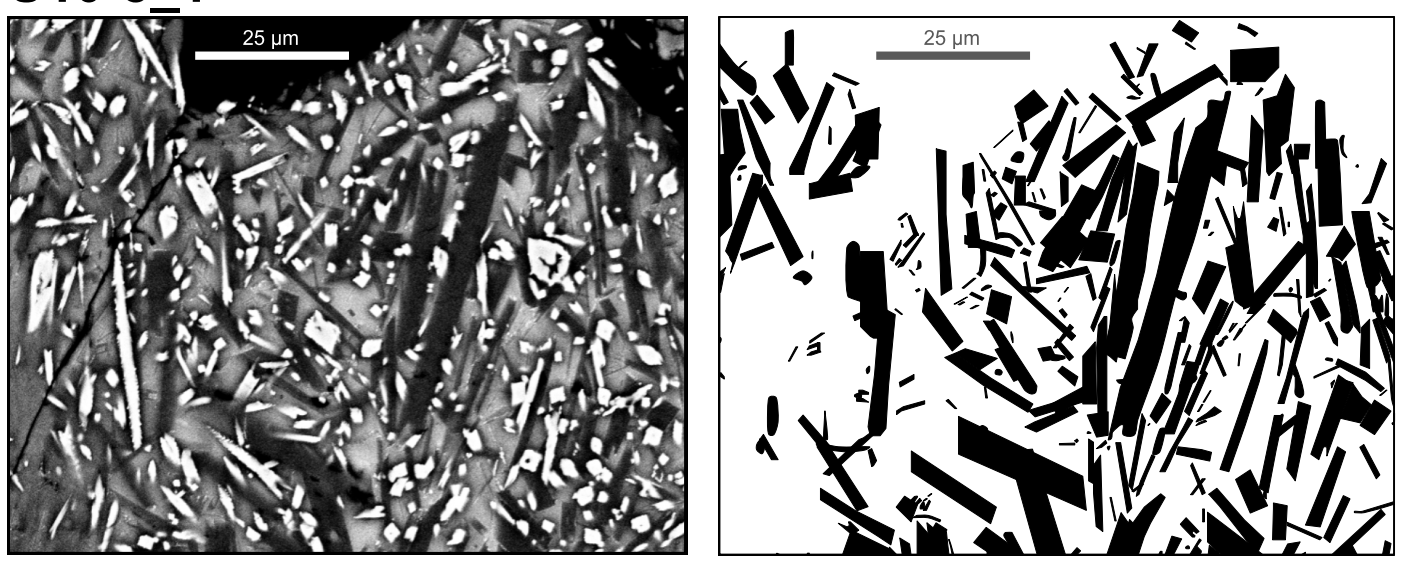

U10-10
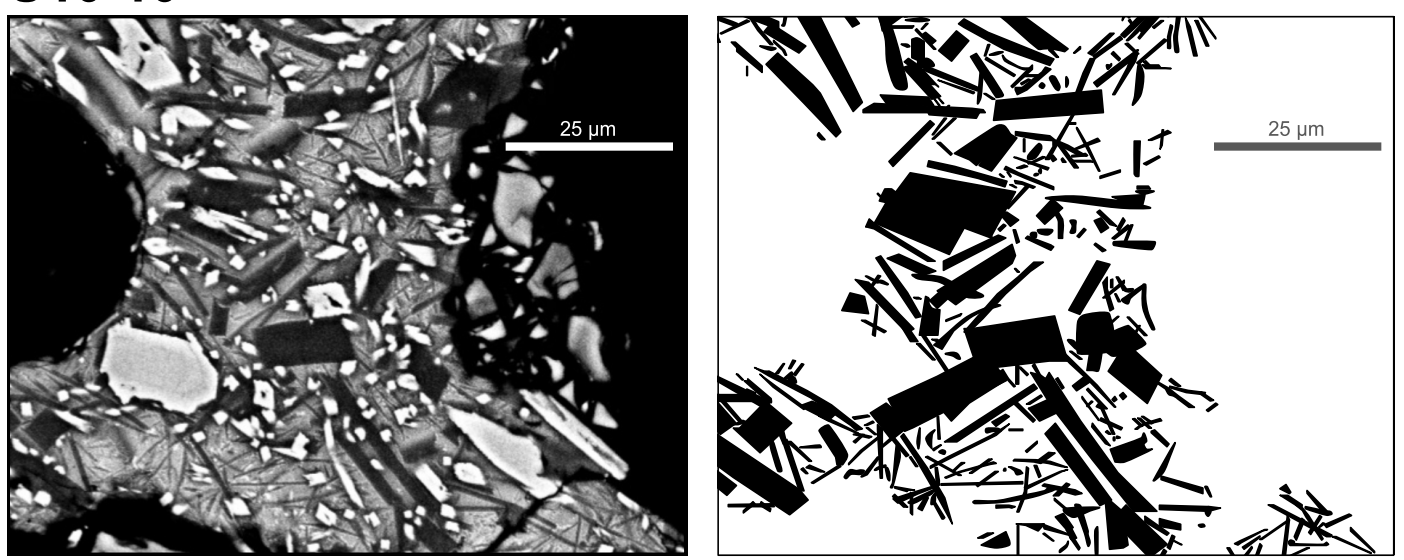

Figure S7: Examples of manually outlined plagioclase feldspar microlites (black) used for the 2D textural analysis. 

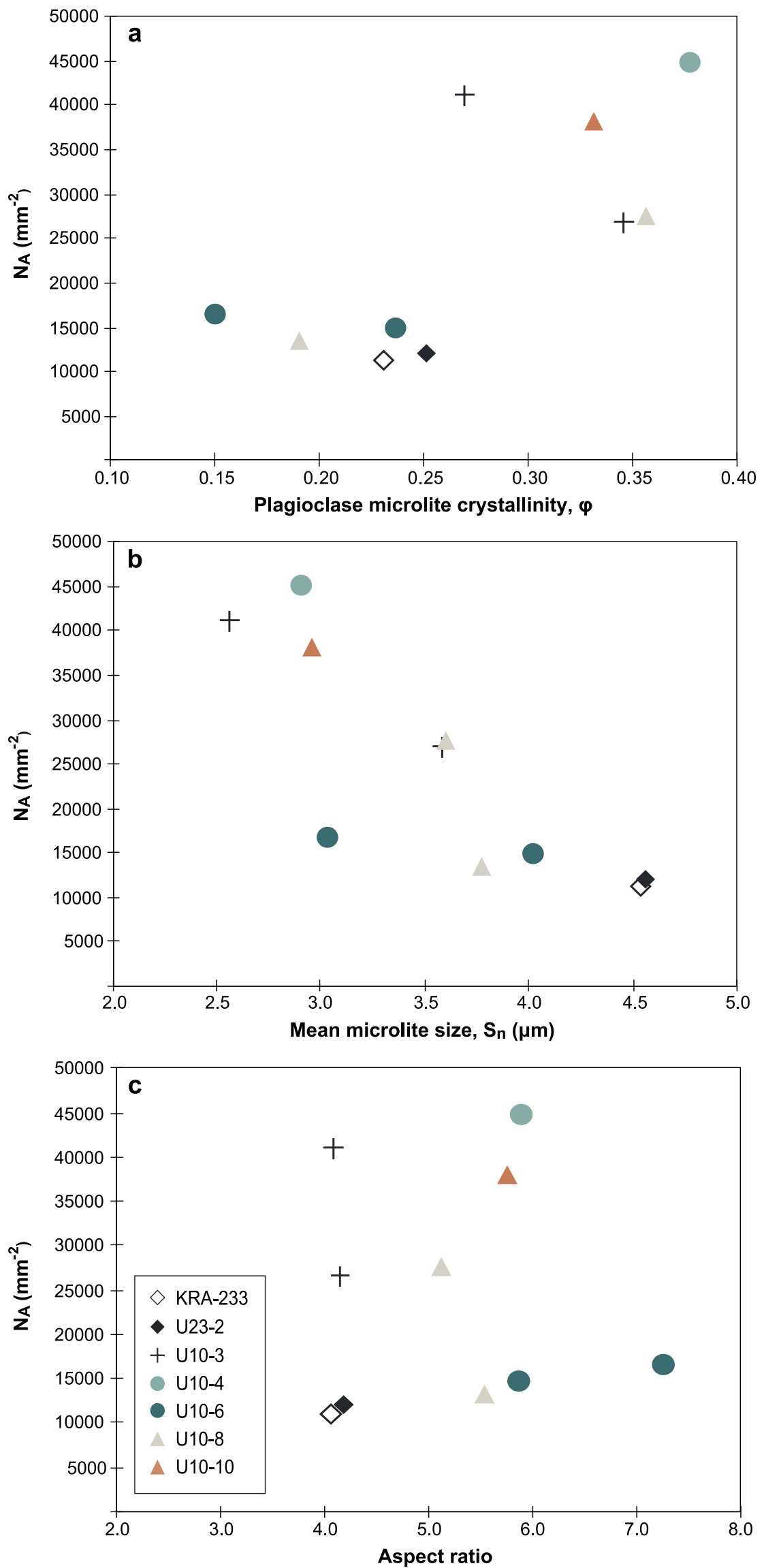

Figure S8: Batch microlite textural parameters for KRA-233, U23-2 and U10 samples. a Areal feldspar microlite number density (NA mm ${ }^{-2}$ ) vs. groundmass feldspar microlite crystallinity $(\varphi)$. b Areal feldspar microlite number density vs. mean microlite size $(S n, \mu \mathrm{m})$. c Areal feldspar microlite number density vs. aspect ratio. 


\section{References}

1. Blott, S.J. and Pye, K., 2001. GRADISTAT: a grain size distribution and statistics package for the analysis of unconsolidated sediments. Earth surface processes and Landforms, 26(11), pp.1237-1248.

2. Cashman, K.V., 1992. Groundmass crystallization of Mount St. Helens dacite, 1980-1986: a tool for interpreting shallow magmatic processes. Contributions to Mineralogy and Petrology, 109(4), pp.431-449.

3. Cashman, K.V. and Edmonds, M., 2019. Mafic glass compositions: a record of magma storage conditions, mixing and ascent. Philosophical Transactions of the Royal Society A, 377(2139), p.20180004.

4. Folk, R.L. and Ward, W.C., 1957. Brazos River bar [Texas]; a study in the significance of grain size parameters. Journal of Sedimentary Research, 27(1), pp.3-26.

5. Gardner, M.F., Troll, V.R., Gamble, J.A., Gertisser, R., Hart, G.L., Ellam, R.M., Harris, C. and Wolff, J.A., 2012. Crustal differentiation processes at Krakatau volcano, Indonesia. Journal of Petrology, 54(1), pp.149-182.

6. Grilli, S.T., Zhang, C., Kirby, J.T., Grilli, A.R., Tappin, D.R., Watt, S.F.L., Hunt, J.E., Novellino, A., Engwell, S., Nurshal, M.E.M. and Abdurrachman, M., 2021. Modeling of the Dec. 22nd 2018 Anak Krakatau volcano lateral collapse and tsunami based on recent field surveys: Comparison with observed tsunami impact. Marine Geology, p.106566.

7. Gualda, G.A. and Ghiorso, M.S., 2015. MELTS _ Excel: A Microsoft Excel-based MELTS interface for research and teaching of magma properties and evolution. Geochemistry, Geophysics, Geosystems, 16(1), pp.315-324.

8. Hammer, J.E., Cashman, K.V. and Voight, B., 2000. Magmatic processes revealed by textural and compositional trends in Merapi dome lavas. Journal of Volcanology and Geothermal Research, 100(1-4), pp.165-192.

9. Jochum, K.P., Stoll, B., Herwig, K., Willbold, M., Hofmann, A.W., Amini, M., Aarburg, S., Abouchami, W., Hellebrand, E., Mocek, B. and Raczek, I., 2006. MPI-DING reference glasses for in situ microanalysis: New reference values for element concentrations and isotope ratios. Geochemistry, Geophysics, Geosystems, 7(2).

10. Kopp, H., Flueh, E.R., Klaeschen, D., Bialas, J. and Reichert, C., 2001. Crustal structure of the central Sunda margin at the onset of oblique subduction. Geophysical Journal International, 147(2), pp.449474.

11. Liu, E.J., Cashman, K.V., Rust, A.C. and Gislason, S.R., 2015a. The role of bubbles in generating fine ash during hydromagmatic eruptions. Geology, 43(3), pp.239-242.

12. Liu, E.J., Cashman, K.V. and Rust, A.C., 2015b. Optimising shape analysis to quantify volcanic ash morphology. GeoResJ, 8, pp.14-30.

13. Putirka, K.D., 2008. Thermometers and barometers for volcanic systems. Reviews in mineralogy and geochemistry, 69(1), pp.61-120.

14. R Core Team, 2013. R: A language and environment for statistical computing. Available at: https://www.R-project.org/.

15. Walter, T.R., Haghighi, M.H., Schneider, F.M., Coppola, D., Motagh, M., Saul, J., Babeyko, A., Dahm, T., Troll, V.R., Tilmann, F. and Heimann, S., 2019. Complex hazard cascade culminating in the Anak Krakatau sector collapse. Nature communications, 10(1), pp.1-11.

16. Ward Jr, J.H., 1963. Hierarchical grouping to optimize an objective function. Journal of the American statistical association, 58(301), pp.236-244. 
17. Wieser, P., Petrelli, M., Lubbers, J., Wieser, E., Kent, A., Till, C., 2021. Thermobar: A critical evaluation of mineral-melt thermobarometry and hygrometry in arc magmas using a new open-source Python3 tool. GSA connects 2021. Portland. 